\title{
Public health risks related to food safety issues in the food market: a systematic literature review
}

\author{
Zemichael Gizaw(D
}

\begin{abstract}
Background: Food safety in the food market is one of the key areas of focus in public health, because it affects people of every age, race, gender, and income level around the world. The local and international food marketing continues to have significant impacts on food safety and health of the public. Food supply chains now cross multiple national borders which increase the internationalization of health risks. This systematic review of literature was, therefore, conducted to identify common public health risks related to food safety issues in the food market.

Methods: All published and unpublished quantitative, qualitative, and mixed method studies were searched from electronic databases using a three step searching. Analytical framework was developed using the PICo (population, phenomena of interest, and context) method. The methodological quality of the included studies was assessed using mixed methods appraisal tool (MMAT) version 2018. The included full-text articles were qualitatively analyzed using emergent thematic analysis approach to identify key concepts and coded them into related non-mutually exclusive themes. We then synthesized each theme by comparing the discussion and conclusion of the included articles. Emergent themes were identified based on meticulous and systematic reading. Coding and interpreting the data were refined during analysis.
\end{abstract}

Results: The analysis of 81 full-text articles resulted in seven common public health risks related with food safety in the food market. Microbial contamination of foods, chemical contamination of foods, food adulteration, misuse of food additives, mislabeling, genetically modified foods (GM foods), and outdated foods or foods past their use-by dates were the identified food safety-related public health risks in the food market.

Conclusion: This systematic literature review identified common food safety-related public health risks in the food market. The results imply that the local and international food marketing continues to have significant impacts on health of the public. The food market increases internationalization of health risks as the food supply chains cross multiple national borders. Therefore, effective national risk-based food control systems are essential to protect the health and safety of the public. Countries need also assure the safety and quality of their foods entering international trade and ensure that imported foods conform to national requirements.

Keywords: Public health risks, Public health hazards, Public health problems, Food safety, Food quality, Food hygiene, Food marketing

\footnotetext{
Correspondence: zemichael12@gmail.com

Department of Environmental and Occupational Health and Safety, Institute

of Public Health, College of Medicine and Health Sciences, University of

Gondar, Gondar, Ethiopia
}

(c) The Author(s). 2019 Open Access This article is distributed under the terms of the Creative Commons Attribution 4.0 International License (http://creativecommons.org/licenses/by/4.0/), which permits unrestricted use, distribution, and reproduction in any medium, provided you give appropriate credit to the original author(s) and the source, provide a link to the Creative Commons license, and indicate if changes were made. The Creative Commons Public Domain Dedication waiver (http://creativecommons.org/publicdomain/zero/1.0/) applies to the data made available in this article, unless otherwise stated. 


\section{Background}

Food safety is an important issue that affects all of the world's people. Many countries throughout the world are increasingly interdependent on the availability of their food supply and on its safety. Hence, people all over the world increasingly value food safety; food production should be done safely to maximize public health gains and environmental benefits. Food safety deals with safeguarding the food supply chain from the introduction, growth, or survival of hazardous microbial and chemical agents $[1,2]$.

Unsafe food containing harmful bacteria, viruses, parasites, or chemical substances causes more than 200 diseases-ranging from diarrhea to cancers. An estimated 600 million in the world fall ill after eating contaminated food and 420,000 die every year, resulting in the loss of 33 million disability adjusted life years (DALYs). Children under 5 years of age carry $40 \%$ of the food borne disease burden, with 125,000 deaths every year. Diarrheal diseases are the most common illnesses resulting from the consumption of contaminated food, causing 550 million people to fall ill and 230,000 deaths every year [3].

Food safety is being challenged nowadays by the global dimensions of food supply chains $[1,4,5]$. Foods in the international market may be frauded as different parties such as manufacturers, co-packers, distributors, and others along the chain of distribution involve in the national or international trade [6-8]. Food safety in the food market is one of the key areas of focus in public health, because it affects people of every age, race, gender, and income level around the world. The local and international food marketing continues to have significant impacts on food safety and health of the public. Food supply chains now cross multiple national borders which increase the internationalization of health risks [9-14]. This systematic review of literature was, therefore, conducted to identify common public health risks related to food safety issues in the food market. This review provides evidence to improve food safety in the food market using risk-based food safety strategies. Healthcare providers, researchers, and policy makers may use the results of this systematic literature review to protect the public from undue health effects due to consumption of foods with poor quality and safety.

\section{Methods}

\section{Research question}

What food safety-related public health risks are commonly found in the food market?

\section{Analytical framework}

We developed the components of the analytical framework using the PICo (population, phenomena of interest, and context) method. The population for this review was the public over the globe. The phenomenon of interest for this review was public health risks associated with food safety. The context was the food market (such as restaurants, food stores, supermarkets, shops, food processing plants, and street vending). The reviewers sat together to discuss and refine the framework.

\section{Criteria for considering studies for this review}

All published and unpublished quantitative, qualitative, and mixed method studies conducted on food safety-related health risks for the general public in the food market were included. Governmental and other organizational reports were also included. Articles published other than English language, citations with no abstracts and/or full texts, duplicate studies, and studies with poor quality were excluded.

\section{Search strategy}

We searched published articles/or reports from MEDLINE/ PubMed, EMBASE, CINAHL, Access Medicine, Scopus, Web of Science, Google Scholar, WHO Library, FAO Libraries, and WTO Library. We also searched thesis and dissertations from Worldcat and ProQuest. We used a three step searching. In the first step, we conducted an initial limited search of MEDLINE and analyzed the text words contained in the title and abstract, and of the index terms used to describe articles. Secondly, we searched across all included databases using all identified keywords and index terms. Thirdly, references of all identified articles were searched to get additional studies. The search term we used in the initial searching is presented as follows.

(((("public health"[MeSH Terms] OR ("public"[All Fields] AND "health"[All Fields]) OR "public health"[All Fields]) AND ("risk"[MeSH Terms] OR "risk"[All Fields] OR "risks"[All Fields])) OR (("public health"[MeSH Terms] OR ("public"[All Fields] AND "health"[All Fields]) OR "public health"[All Fields]) AND hazards[All Fields])) OR (("public health"[MeSH Terms] OR ("public"[All Fields] AND "health"[All Fields]) OR "public health"[All Fields]) AND problems[All Fields])) AND ((("food safety"[MeSH Terms] OR ("food"[All Fields] AND "safety"[All Fields]) OR "food safety"[All Fields]) OR ("food quality"[MeSH Terms] OR ("food"[All Fields] AND "quality"[All Fields]) OR "food quality"[All Fields])) OR (("food"[MeSH Terms] OR "food"[All Fields]) AND ("hygiene"[MeSH Terms] OR "hygiene"[All Fields])))) AND ((("food"[MeSH Terms] OR "food"[All Fields]) AND market[All Fields]) OR (("food"[MeSH Terms] OR "food"[All Fields]) AND trade[All Fields])) OR (("food supply"[MeSH Terms] OR ("food"[All Fields] AND "supply"[All Fields]) OR "food supply"[All Fields]) AND chain[All Fields])) 


\section{Assessment of methodological quality}

Search results from different electronic databases were exported to Endnote reference manager to remove duplication. Two independent reviewers (ZG and BA) screened out articles using titles and abstracts. The reviewers further investigated and assessed full-text articles against the inclusion and exclusion criteria. The reviewers sat together to resolve disagreements during the review. The methodological quality of the included studies was assessed using mixed methods appraisal tool (MMAT) version 2018 [15]. This method explains the detail of each criterion. The rating of each criterion was, therefore, done as per the detail explanations included in the method. Almost all of the included full-text articles fulfilled the criteria and all the included full-text articles were found to be better quality.

\section{Data extraction}

In order to minimize bias, we the reviewers independently extracted data from papers included in the review using JBI mixed methods data extraction form [16]. The data extraction form was piloted on randomly selected papers and modified accordingly. Eligibility assessment was performed independently by the two reviewers. Information like authors, year of publication, study areas, type of studies, and focus of the study or main messages were extracted.

\section{Synthesis of findings}

The included full-text articles were qualitatively analyzed using emergent thematic analysis approach to identify key concepts and coded them into related non-mutually exclusive themes. We then synthesized each theme by comparing the discussion and conclusion of the included articles. Emergent themes were identified based on meticulous and systematic reading. Coding and interpreting the data were refined during the analysis.

\section{Results}

\section{The search process}

The search strategy identified 2641 titles and abstracts (1890 from PubMed and 751 from other sources) as of 13 June 2019. We obtained 1992 title and abstracts after we removed duplicates. Following assessment by title and abstract, 705 articles were retrieved for more evaluation and 344 articles were assessed for eligibility. Finally, 81 articles were included for systematic literature review based on the inclusion criteria (Fig. 1).

In this review, 81 of 1992 (4\%) full-text articles matched the inclusion criteria. The overwhelming majority, 74 of 81 (91\%) of the included full-text articles are research articles; $2(3 \%)$ are short communications; 2 (3\%) are regulatory papers, 1 (1\%) is field inspection; 1 (1\%) is research note; and the other $1(1 \%)$ is thesis. Of the included full-text articles, 30 of $81(37 \%)$ are conducted in Asia; 4 of 81 (5\%) are conducted in multiple countries in the same region or across regions; and 1of 81 (1\%) is not region specific (Fig. 2).

All the included full-text articles are published between 1991 and 2018 (35 (43\%) between 2011 and 2015; 16 (20\%) between 2000 and 2005; 16 (20\%) between 2006 and 2010; 12 (15\%) between 2016 and 2018; and the rest 2(2\%) before 2000).

\section{Food safety-related public health risks identified from the search process}

The analysis of 81 full-text articles resulted in seven common public health risks related with food safety in the food market. Microbial contamination of foods, chemical contamination of foods, food adulteration, misuse of food additives, mislabeling, GM foods, and foods past their use-by dates were the identified food safetyrelated health risks in the food market (Table 1).

Table 2 shows food safety-related public health risks in the food market by country name (countries are categorized into developed and developing based on the United Nations (UN) 2019 list). Among 21 full-text articles included for microbial contamination of foods, 13 (62\%) were from developing countries. This may suggest microbial contamination of foods in the food market is a common public health risk in developing countries than the developed. Eight (53\%) of 15 articles retrieved for chemical contamination of foods in the food market were from developing countries. The vast majority, 8 of 9 (89\%) full-text articles retrieved for food adulteration were from developing countries, which may indicate adulteration of foods is practiced more of in developing countries. Similarly, 8 of 11 (73\%) of the full-text articles included for misuse of food additives were from developing countries, which may show misuse of food additives is a common problem in developing countries. For mislabeling, 14 of 17 (82\%) and 8 of 17 (47\%) of the full-text articles were from developed and developing countries respectively. Four out of six (67\%) of full-text articles retrieved for foods past use-by dates were from developing countries. This may show selling of outdated foods is common in developing countries than the developed.

Figure 3 shows comparison of food safety issues in developed and developing countries. A total of 37 and 50 articles were included in this review from developed and developing countries respectively. The comparison of food safety issues among developed countries suggests that mislabeling (38\%), microbial contaminations (22\%), and chemical contamination (19\%) are the commonest food safety issues in the food market. Similarly, the comparison of food safety issues among developing countries suggests that microbial contaminations (26\%), chemical contaminations (16\%), food adulteration (16\%), misuse 


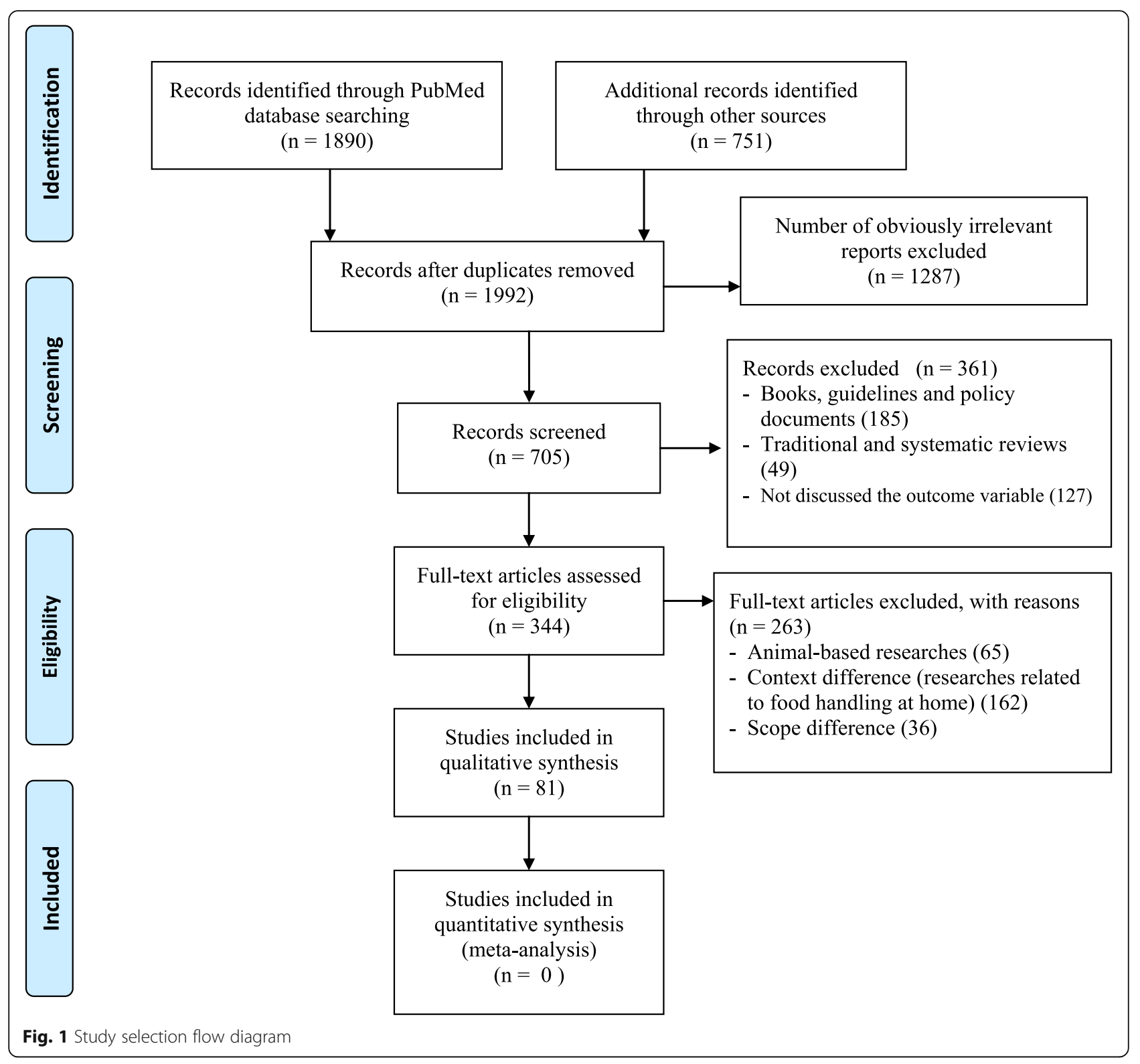

of additives (16\%), and mislabeling (16\%) are the commonest food safety issues in the food market.

\section{Microbial contamination of foods}

In this review, 21 of 81 (26\%) full-text articles reported the presence of pathogenic microorganisms in different food items in the food market. These studies identified different diseases causing bacteria mainly Salmonella spp., Escherichia coli, Klebsiella spp., Shigella spp., Enterobacter spp., Proteus spp., Citrobacter spp. Staphylococcus aureus, Campylobacter spp., Listeria spp., Vibrio, Alklegens spp., Bacillus cereus, Pseudomonas spp., Clostridium perfringens, Arcobacter spp., and Enterococcus spp. Moreover, different fungus such as Blastomyces, Fusarium spp., Mucor spp., Aspergillus niger, Fusarium avenaceum, Penicillium digitatum, Rhizopus stolonifer, Saccharomyces species, Fusarium solani, Aspergillus flavus, Saccharomyces dairensis, and Saccharomyces exiguus were identified from different food items from food stores or shops. The included studies also reported that some of the microorganisms are resistant to different antimicrobials (Table 3). The results also show that total coliforms, fecal coliforms, and different fungus were commonly reported in developing countries than developed countries. On the other hand, different Campylobacter species were reported in developed countries than developed countries.

\section{Chemical contamination of foods}

Fifteen (19\%) of the full-text articles included in this review reported that contamination of foods with hazardous chemicals is a major public health concern 


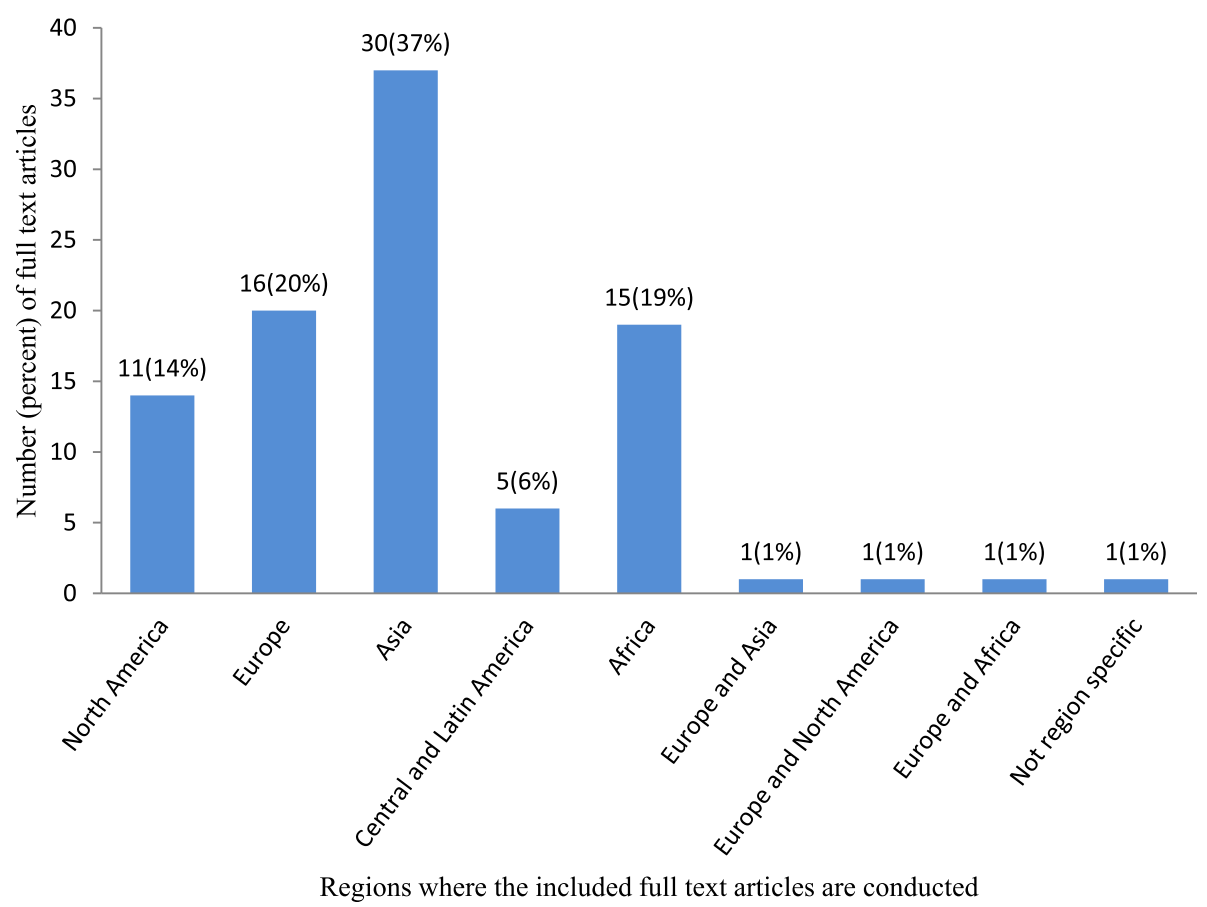

Fig. 2 Regions where the included full-text articles conducted

associated with the food market. Heavy metals (like cadmium, nickel, lead, copper, zinc, iron, mercury, and manganese), pesticide residuals (like dichlorvos, dimethoate, parathion-methyl, pirimiphos-methyl, and parathion), persistent organic pollutants (like dichlorodiphenyltrichloroethane metabolites, polychlorinated biphenyls, perfluorooctanoic acid, endosulfans, and aldrin), organic compounds (like patulin, chloroform, formalin, and urea), volatile organic compounds (like ethyl benzene, o-xylene, and benzene), hydrocarbons (like benzo[a]pyrene and toluene), and other chemical compounds (like calcium carbide and cyanide) are chemical contaminants identified by the full-text articles included in this review. In most cases, the concentration of chemicals exceeded the tolerable limit for consumable food items (Table 4).

Table 1 Common food safety-related public health risks identified from the search process

\begin{tabular}{ll}
\hline Common public health risks related with food safety & Number of papers \\
\hline Microbial contamination of foods & 21 \\
Chemical contamination of foods & 15 \\
Food adulteration & 9 \\
Misuse of food additives & 11 \\
Mislabeling & 17 \\
Genetically modified foods & 4 \\
Foods past their use-by dates & 6 \\
\hline
\end{tabular}

\section{Food adulteration}

In $9(11 \%)$ of full-text articles included in this review, food adulteration has been discussed as a major public health risk associated with food safety issues in the food market. Most of the foodstuffs in the market are adulterated in varying degrees. Chemicals (like urea fertilizer, artificial color flavors, textile dye, formalin, chlorofluorocarbon; DDT powder, sodium bicarbonate, neutralizers, detergents, hydrogen peroxide, caustic soda, sodium chloride, boric acid, ammonium sulfate, sorbitol, metanil yellow, ultramarine blue, rhodamine B., maleic anhydride, copper chlorophyll, dimethyl/diethyl yellow, argemone oil, burnt mobil, and burnt oil); items which are not the genuine component of foods (like potato smash, cow's fat and intestine in ghee, water in milk, sugar in honey, etc.); poor-quality products; and physical or inert agents (like saw dust and brick powder) are the commonest adulterants added to different food items (Table 5).

\section{Misuse of food additives}

In this systematic review of literature, 11 of $81(14 \%)$ full-text articles showed that misuse of food additives in the food market endangers public health. As reported in the included full-text articles, even though some food colorants and sweeteners are permitted to use such as sunset yellow FCF (SSYFCF), tartrazine, erythrosine, new coccine, ponceau, and saccharin (some may not be permitted based on countries food 
Table 2 Food safety-related public health risks in the food market by country name (countries are categorized into developed and developing based on the United Nations (UN) 2019 list)

\begin{tabular}{|c|c|c|}
\hline \multirow[t]{2}{*}{ Food safety issues } & \multicolumn{2}{|c|}{ Countries where the included full-text articles are conducted } \\
\hline & Developed & Developing \\
\hline \multirow[t]{10}{*}{ Microbial contamination (21) } & Italy & Philippines \\
\hline & USA & Nigeria (2) \\
\hline & Greece (2) & Mexico (2) \\
\hline & Spain (2) & Sudan \\
\hline & UK (2) & India (2) \\
\hline & & South Africa \\
\hline & & Iran \\
\hline & & Thailand \\
\hline & & Tanzania \\
\hline & & Bangladesh \\
\hline \multirow[t]{5}{*}{ Chemical contamination (15) } & Saudi Arabia (2) & China (2) \\
\hline & USA & Tunisia \\
\hline & Belgium (2) & Nigeria (2) \\
\hline & Canada & Egypt \\
\hline & Italy & Bangladesh (2) \\
\hline \multirow[t]{4}{*}{ Food adulteration (9) } & Taiwan & Bangladesh (3) \\
\hline & & India (2) \\
\hline & & Pakistan \\
\hline & & Ethiopia (2) \\
\hline \multirow[t]{4}{*}{ Misuse of additives (11) } & USA (2) & India (4) \\
\hline & Taiwan & Pakistan(2) \\
\hline & & Iran \\
\hline & & Indonesia \\
\hline \multirow[t]{7}{*}{ Mislabeling (17) ${ }^{\mathrm{a}}$} & Ireland & China \\
\hline & USA (3) & Malaysia \\
\hline & Italy (3) & India \\
\hline & Spain (4) & Egypt (2) \\
\hline & Greek & South Africa \\
\hline & Canada & Brazil (2) \\
\hline & Belgium & \\
\hline \multirow[t]{2}{*}{ Genetically modified foods $(4)^{b}$} & USA & Eastern Caribbean \\
\hline & Canada & \\
\hline \multirow[t]{4}{*}{ Food past use-by dates (6) } & Canada & Nigeria \\
\hline & USA & Indonesia \\
\hline & & Bangladesh \\
\hline & & Kenya \\
\hline
\end{tabular}

Numbers in the bracket show the number of full-text articles included

${ }^{a}$ There are studies conducted in two and/or three different countries. In this case, we may count one study twice and /or three times.

${ }^{b}$ One study was conducted in a general context. So, we did not include it when we categorize studies in regions

regulation), their concentration exceeded the prescribed limit. Moreover, use of non-permitted colorants and sweeteners such as rhodamine B, metanil yellow, orange II, malachite green, auramine, quinoline yellow, amaranth, carmoisine, Sudan dyes, and cyclamate (some may be permitted based on countries food regulation) is also commonly reported in the included studies (Table 6). 


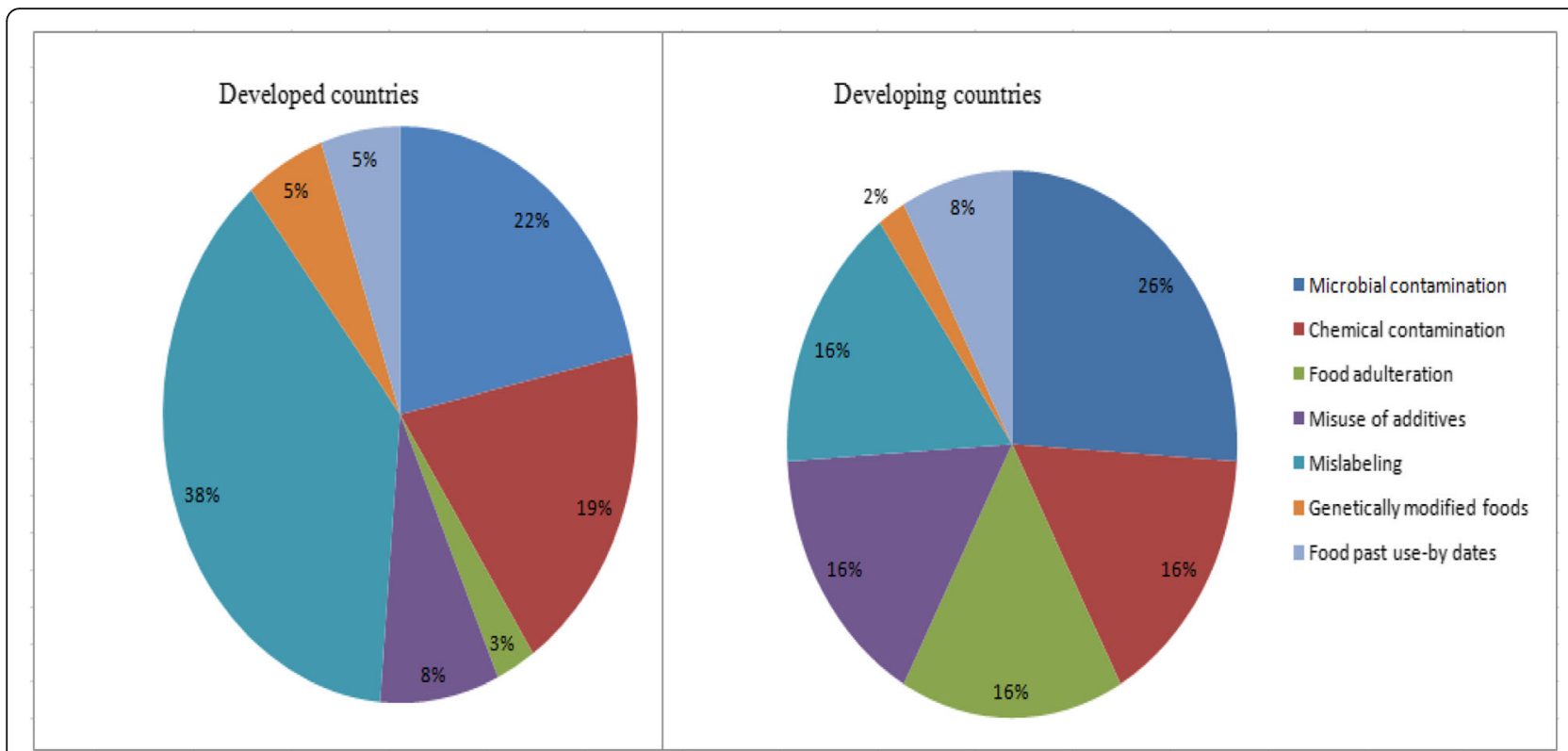

Fig. 3 Comparison of food safety issues in developed and developing countries

\section{Mislabeling}

Mislabeling of food products has been mentioned as a major public health risk associated with food safety in the food market in 17 of 81 (21\%) full-text articles included in this review. All of the 17 studies reported that significant proportion of food samples collected from supermarkets, food stores, shops, and restaurants were genetically identified as entirely different species from that identified on the product labels, and therefore were considered as mislabeled. The studies witnessed that seafood is the most commonly mislabeled food product (Table 7).

\section{Genetically modified foods}

In this systematic review of literature, 4 of 81 (5\%) of the included full-text articles discussed that GM foods are becoming an increasing public health risk. Hypertension, stroke, diabetes, obesity, lipoprotein metabolism disorder, Alzheimer's, Parkinson's, multiple sclerosis, hepatitis C, end-stage renal disease, acute kidney failure, cancers of the thyroid/liver/bladder/pancreas/kidney, myeloid leukemia, diarrhea, vomiting, difficulty in breathing, respiratory problems, hormonal imbalances and susceptibility to infection or immunosuppression, allergenic or rashes, and chemical toxicity are health problems reported in the included fulltext articles (Table 8).

\section{Foods past their use-by dates}

Six $(7 \%)$ of the included full-text articles revealed that outdated or foods past their use-by dates are being sold in food stores, shops, and restaurants which are contributing huge public health and environmental problems (Table 9).

\section{Discussion}

This review identified that microbial contamination, chemical contamination, adulteration, misuse of food additives, mislabeling, genetically modified foods, and outdated foods are common public health risks related with food safety issues in the food market. In the food market, food can become contaminated in one country and cause health problems in another. These food safety issues cause exposure of consumers to biological, chemical, and physical hazards [91-95] so that endanger health of the public. The origin of food hazards can be described as a chain which commences on the source and continues with transportation, further processing steps, merchandising events and finally ends with the consumer [96-100]. Overall, this review suggested that food safety-related public health risks are more common in developing countries than developed countries. This can be justified that foods get easily contaminated with microbes due to the poor hygiene and sanitation in developing countries [101-104]. Moreover, hence the regulatory services are weak in developing countries, most food sellers may not comply with food hygiene and safety requirements or standards [105-107]. In developing countries, the legislation enforcement is still weak about administrating the concentration of harmful contaminants in the food $[108,109]$. In addition, there is inadequate information and technology to detect fake and fraud products [110-112]. 
Table 3 Summary of full-text articles which reported microbial contamination of foods as a public risk in food marketing

\begin{tabular}{|c|c|c|c|}
\hline Authors & Country/region & Article type & Main message/findings \\
\hline Gabriel AA, et al., 2007 [17] & Philippines & Research article & $\begin{array}{l}\text { This study assessed the microbiological quality of retailed mung bean } \\
\text { sprouts. Ninety-four percent of the samples tested positive for the } \\
\text { presence of Salmonella spp. and some samples had Coliform and } \\
\text { Escherichia coli counts as high as } 5.90 \text { and } 5.50 \log _{10} \mathrm{CFU} \mathrm{g} \mathrm{g}^{-1} \text {, } \\
\text { respectively. The poor microbiological quality of most of the tested } \\
\text { sprouts was attributed to unhygienic sprout production and retailing } \\
\text { practices. }\end{array}$ \\
\hline
\end{tabular}

Adeyanju GT and Ishola O, Nigeria Research article 2014 [18]

Giammanco GM, et al., 2011 [19]

Zhao C, et al., 2001 [20]

USA

Research article

Cárdenas C, et al., 2013 [21] Mexico

Research article

Filiousis G, et al., 2009 [22]

Greece

Pérez-Rodríguez $\mathrm{F}$, et al., 2010 [23]

Yagoub SO, 2009 [24]

Sudan

Research article

Kumari S and Sarkar PK, 2014 [25] practices.

Accessed the levels of Salmonella and Escherichia coli in frozen poultry meats including their antimicrobial resistance pattern in Ibadan. Thirtythree percent and $43.4 \%$ of samples from retail markets tested positive for Salmonella and Escherichia coli respectively. Salmonella enterica spp. showed $93 \%$ resistance to tetracycline and $100 \%$ resistance to augmentin and amoxicillin, while Escherichia coli showed 100\% resistance to augmentin and amoxicillin.

This study assessed common food pathogens in cheese collected from retailing markets in Palermo. The result indicated that $4 \%$ and $44 \%$ of the samples, respectively, did not comply with the acceptability levels for $S$. aureus and E. coli. A high contamination of bacteria belonging to Enterobacteriaceae and Staphylococcaceae was found in $42 \%$ and $50 \%$ of the cheeses analyzed, respectively. The results indicated that poor husbandry and poor hygiene practices during milk collection or preservation or during cheese production processes and handling. In addition, the retail sale conditions may have played a role in cheese contamination.

This study assessed the prevalence of common food pathogens from retail raw meats in Washington, DC. Results of the study showed that 70.7\% of chicken samples were contaminated with Campylobacter. Approximately $14 \%$ of turkey samples yielded Campylobacter, whereas fewer pork (1.7\%) and beef (0.5\%) samples were positive for Campylobacter. Thirty-eight point seven percent of chicken samples yielded E. coli, while $19.0 \%$ of the beef samples, $16.3 \%$ of the pork samples, and $11.9 \%$ of the turkey samples were positive for E. coli. However, only $3.0 \%$ of the retail meat samples tested were positive for Salmonella.

This study evaluated the microbiological quality of tomatoes and peppers from markets and supermarkets in Monterrey, Mexico. The results showed that the presence of indicator organisms was relatively high in peppers (average 4.4 to $4.7 \mathrm{log}$ CFU/g for total mesophilic, 3.25 to $3.73 \mathrm{log}$ CFU/g for total coliforms, and $1.69 \mathrm{log}$ CFU/g for fecal coliforms). Tomatoes and peppers showed the greatest microorganism levels $(\sim 1$ log CFU/g higher) in comparison with the other varieties.

Short communication This study analyzed prevalence, genetic diversity, and antimicrobial susceptibility of Listeria monocytogenes isolated from open-air food markets in Thessaloniki, Greece. Thirty (14.3\%) contained L. monocytogenes with the highest prevalence in raw meat (27.5\%), raw meat products $(18 \%)$, and cheese (8\%). The strains were susceptible to 16 antimicrobials, except one strain which displayed resistance to tetracycline.

This study evaluated hygiene practices and microbiological quality of cooked meat products during slicing and handling at retail in Cordoba, Spain. Listeria monocytogenes and Listeria inocua were isolated from $7.35 \%$ $(5 / 68)$ and $8.82 \%(6 / 68)$ of analyzed samples, respectively. Deficient handling practices were more common in small sized establishments.

This study aimed to isolate Enterobacteriaceae and Pseudomonas spp. from raw fish sold in fish market in Khartoum. Enterobacteriaceae were isolated from 83 out of 150 (55\%) randomly collected fishes, the most dominant isolates were E. coli, Citrobacter spp., Enterobacter spp., and Klebsiella spp. This together with the highly pathogenic Enterobacteriaceae including Salmonella spp. and Shigella spp., Proteus spp., and Alklegens spp. Potential pathogenic organisms were also among the isolates. On the other hand, Pseudomonas spp. were isolated from 62\% of randomly collected fishes.

This study characterized Bacillus cereus group from various marketed dairy products in India. The prevalence of B. cereus group in cheese, ice cream, milk powder, and milk was high (33-55\%), whereas it was low in butter and paneer samples (20\% and $4 \%$, respectively). The level of 
Table 3 Summary of full-text articles which reported microbial contamination of foods as a public risk in food marketing (Continued)

\begin{tabular}{|c|c|c|}
\hline Authors & Country/region & Article type \\
\hline Domınguez C, et al., & Spain & Research article \\
\hline
\end{tabular}

2002 [26]

Vantarakis $A$, et al., 2011 [27]

Heredia N, et al., 2001 [28]

Nel S, et al., 2004 [28]

Elson R, et al., 2004 [29]

Hosseini A. 2011 [30]

Banerjee $\mathrm{M}$ and

Sarkar PK, 2003 [31]

Vindigni SM, et al., 2007 [32]
South Africa

Research article

UK

Research article

Iran

India

Greece

Research article

Mexico

Research note

Research article

Thailand

Research article
Main message/findings

contamination in the various dairy products was up to $10^{8} \mathrm{cfu} \mathrm{g}^{-1}$ or $\mathrm{ml}^{-1}$. An antibiogram of 144 isolates of $B$. cereus group was obtained using 14 different antibiotics commonly used against foodborne diseases. All the 144 isolates were multidrug (at least five antibiotics) resistant.

This study assessed prevalence of Salmonella and Campylobacter in retail chicken meat in Spain. Salmonella was isolated from 71 (35.83\%) of the samples analyzed. The predominant serovars were $S$. enteritidis (47.88\%), S. hadar (25.35\%), and serotype 4,12:b:-(II) (19.71\%). Other serovars such as S. mbandaka, S. derby, S. virchow, and S. paratyphi B were isolated in much lower levels. Thermophilic campylobacters were isolated in $49.50 \%$ of the samples studied.

This study assessed occurrence of microorganisms of public health and spoilage significance in fruit juices sold in retail markets in Greece. Bacteria were isolated from 51 samples (42.5\%) and fungi from 78 samples (65\%). Escherichia coli 0157:H7 was detected in four of the analyzed samples (3.34\%), and Staphylococcus aureus was detected in four different samples (3.34\%). In 11 samples (9.1\%), the total number of microorganisms detected was as high as 125 CFU. Acidophilic microorganisms were isolated from 26 samples (21.7\%) and Blastomyces was detected in 46 samples (38.3\%)

This study assessed microbiological Condition of Ground Meat Retailed in Monterrey, Mexico. Over $75 \%$ of the samples contained $10^{5}$ total mesophilic microorganisms per $\mathrm{g}$, and over $40 \%$ had $10^{6}$ total coliforms per g. Fecal coliforms were present in most samples. Staphylococcus aureus was detected in 2.3\% of the samples, Salmonella spp. in 11.4\%, Listeria spp. in 62\%, and L. monocytogenes in 16\%. Escherichia coli was detected in $76 \%$ of samples. Fusarium spp. and Mucor spp. were detected in $3.4 \%$ of the samples, and low levels of yeast in $93 \%$.

This study assessed bacterial populations associated with meat from the deboning room of a high-throughput red meat abattoir in South Africa. Almost the counts exceeded the microbiological guidelines for raw meat. The average $B$. cereus count over the sampling period was $8.32 \times 10^{3} \mathrm{cfu}$, $\mathrm{g}^{-1}$, for S. aureus and Pseudomonas spp. $1.72 \times 10^{5}$ and $1.7 \times 10^{5} \mathrm{cfu} \mathrm{g}^{-1}$ respectively and for $E$. coli $3.4 \times 10^{5} \mathrm{cfu} \mathrm{g}^{-1}$. Sixty percent of the samples were positive for presumptive Salmonella spp. while 52\% of the samples tested positive for the presence of $L$. monocytogenes. The aerobic plate and Enterobacteriaceae counts were $1.7 \times 10^{7}$ and $4.6 \times 10^{6} \mathrm{cfu} \mathrm{g}^{-1}$, respectively.

This study examined microbiological quality of ready-to-eat cold sliced meats from catering and retail premises in the UK. Most ready-to-eat meat samples (75\%) were of satisfactory/acceptable microbiological quality and $25 \%$ were of unsatisfactory/unacceptable quality. Two cold meat samples $(<1 \%)$ were of unacceptable microbiological quality because of the presence of Campylobacter jejuni in $25 \mathrm{~g}$ and Listeria monocytogenes at $3.4 \times 10^{4} \mathrm{CFU} \mathrm{g}^{-1}$.

This study examined bacterial contamination of table eggs from retails markets in Iran. The result showed that 19 samples were contaminated by E. coli, four samples by Proteus spp., and one sample by Klebsiella spp. Average colony count of coli form bacteria was $20 \mathrm{cfu} / \mathrm{g}$ and $E$. coli was $12 / 6 \mathrm{cfu} / \mathrm{g}$.

This study investigated microbiological quality of some retail spices in India. The total aerobic mesophilic bacteria count showed that $51 \%$ of the samples were in the unacceptable level $\left(>10^{6} \mathrm{cfu} \mathrm{g}^{-1}\right)$. While molds were detected in $97 \%$ of the samples, yeast was found in only one. Bacillus cereus, Clostridium perfringens, Staphylococcus aureus, and members of Enterobacteriaceae occurred in $85,59,11$, and $85 \%$, respectively of the kinds. Coliforms and fecal coliforms were found in 33 and 15\%, respectively of the kinds. Escherichia coli was detected in only one sample, of garlic. Salmonella and Shigella were found only in $2.6 \%$ of the samples.

This study assessed prevalence of foodborne microorganisms in retail foods in Thailand. Of the 200 samples tested, 121 (61\%) were positive for at least one Salmonella spp. serogroup. A total of 175 Salmonella spp. were isolated. The most common serotype was Salmonella Anatum, followed by S. Corvallis and S. Derby. Campylobacter spp. were found in 
Table 3 Summary of full-text articles which reported microbial contamination of foods as a public risk in food marketing (Continued)

\begin{tabular}{ll}
\hline Authors & Main message/findings \\
\hline & $31(15.5 \%)$ of 200 samples. C. jejuni was isolated from 15\% of fresh market \\
& chicken samples and $35 \%$ of supermarket chicken samples. Arcobacter spp. \\
& were isolated from $42(21 \%)$ samples; fresh market chicken had \\
& significantly higher $A$. butzleri contamination than supermarket chicken. \\
& The presence of Enterococcus spp., an indication of fecal contamination, \\
& was detected in 188 (94\%) samples, including 100\% of the beef and pork \\
& sources.
\end{tabular}

Simforian E, et al., Tanzania $\quad$ Research article 2015 [33]

Mailafia S, et al., 2017 [34] Nigeria Research article

Hunter PR, et al., 1994 [35] England Research article

Islam M, 2017 [36]

Bangladesh Thesis
This study assessed microbiological quality of raw fruit juice in Tanzania. The results showed that the total plate counts (TPC) ranged between 2.32 and 8.54 (Log cfu/ml). About $72.2 \%$ of juice samples had TPC above Codex recommended maximum levels (3.7-4.7 Log cfu/ml). The prevalence of Escherichia coli in the juices was $80 \%$ with a range between 0.0 and 5.0 (Log MPN/ml) suggesting of direct fecal contamination or contamination from the environment.

This study identified fungi associated with spoilt fruits vended in Gwagwalada market. Nigeria Aspergillus niger had the highest occurrence in pineapple, watermelon, oranges, pawpaw, and tomatoes with a frequency of 38\%. Fusarium avenaceum followed with the frequency of occurrence of $31 \%$ in fruits such as pineapple, watermelon, oranges, pawpaw, and tomatoes while Penicillium digitatum and Rhizopus stolonifer had the least frequency of $4 \%$ each in tomato; and orange and tomato, respectively. Other fungal species were identified as yeast (Saccharomyces species) (10\%), Fusarium solani (8\%), and Aspergillus flavus (5\%). The highest prevalence rate was $70 \%$ of $A$. niger from orange followed by $F$. avenaceum of which $65 \%$ isolates were recovered from pawpaw. Other fungal organisms such as yeast (Saccharomyces species), P. digitatum, and R. stolonifer were isolated with varying prevalence (40\%, 20\%, and 5\%) from watermelon, tomato, and orange, respectively.

This study isolated food spoilage yeasts from salads purchased from delicatessens in the Warrington area, England. The results indicated that Of the 87 salads, only $19 \%$ had plate counts greater than 10,000 organisms/g. Coliforms were isolated from 3 samples, E. coli from one, and Listeria monocytogenes from one. By contrast, yeasts were isolated from $76 \%$ of the salads and at counts greater than 10,000 organisms/g in $31 \%$. Twenty-one different yeast species were isolated, of which the most common were Saccharomyces dairensis and Saccharomyces exiguus.

This study assessed bacteriological quality of street-vended and expired food items collected from different areas in Dhaka City, Bangladesh. Out of total $35 f \circ o d$ samples (expired and street), enteric bacteria were found in $17(48.6 \%)$ food samples containing E. coli, Vibrio, Shigella, and Salmonella species.
This review identified that microbial contamination of foods in the food market is commonly reported in many studies. Different bacterial species and funguses were the commonest diseases causing pathogens identified [17$35,113]$. Failure to apply food safety strategies in every stage of the food supply chain, for example bad food handling practices, poor production process, poor agricultural practices, poor transportation system, poor marketing practices, and poor sanitation lead to microbial contamination of foods [114-118]. Moreover, fraud of foods such as adulteration, mislabeling, and selling of spoiled or expired foods are also causing microbial contamination [36, 119-122]. Microbial contamination of foods causes millions of diseases and thousands of deaths [123]. This review also shows that total coliforms, fecal coliforms, and different fungus were commonly reported in developing countries than developed countries. This might be due to the fact that fecal contamination of foods and the environment is common in developing countries due to poor sanitation condition [124-126]. Moreover, the temperature and air system of food storage areas are not well regulated in developing countries. This situation creates favorable condition for molds. On the other hand, different Campylobacter species were reported in developed countries. This might be due to the fact that advancement of molecular techniques to identify these microorganisms. Developing countries lack specialized cultivation techniques to culture these organisms [127]. The standard culture-based technique, which is a predominant detection method in developing countries, is not effective for Campylobacter species [128-130].

Contamination of foods with hazardous chemicals has been reported as a major public health concern associated with the food market in individual studies included in this review [37-46, 48, 131-133]. The phases of food 
Table 4 Summary of full-text articles which reported chemical contamination of foods as a public risk in food marketing

\begin{tabular}{|c|c|c|c|}
\hline Authors & Country/region & Article type & Main message/findings \\
\hline Bai Y, et al., 2006 [37] & China & Research article & $\begin{array}{l}\text { This study investigated the organophosphorus (OP) pesticide residues in } \\
\text { market foods in China. In } 18 \text { of } 200 \text { samples, five OP pesticides, including } \\
\text { dichlorvos, dimethoate, parathion-methyl, pirimiphos-methyl, and } \\
\text { parathion, were found in concentrations ranging from } 0.004 \text { to } 0.257 \mathrm{mg} / \\
\mathrm{kg} \text {. The mean levels of dimethoate in fruits and parathion in vegetables } \\
\text { exceeded the maximum residue limits (MRLs). }\end{array}$ \\
\hline
\end{tabular}

Othman ZAA, 2010 [38] Saudi Arabia Research article

Zaied C, et al., 2013 [39] Tunisia Research article

Schecter A, et al., 2010 [40] USA

Onianwa P, et al., 2001 [41] Nigeria Research article

Vinci RM, et al., 2015 [42] Belgium $\quad$ Research article

Onianwa P, et al., 2000 [41] Nigeria

Radwan MA and Salama AK, Egypt 2006 [44] exceeded the maximum residue limits (MRLs).

This study determined lead contamination in the Riyadh market in Saudi Arabians. Results showed that sweets $(0.011-0.199 \mu \mathrm{g} / \mathrm{g})$, vegetables $(0.002-0.195 \mu \mathrm{g} / \mathrm{g})$, legumes $(0.014-0.094 \mu \mathrm{g} / \mathrm{g})$, eggs $(0.079 \mu \mathrm{g} / \mathrm{g})$, and meat and meat products $(0.013-0.068 \mu \mathrm{g} / \mathrm{g})$ were the richest sources of lead.

This study assessed occurrence of patulin in apple-based foods from supermarkets and stores in Tunisia. Results showed that the incidence of patulin contamination was $35 \%$. The levels of contamination determined in the total samples ranged between 0 and $167 \mathrm{mg} / \mathrm{l}$ with a mean value of $20 \mathrm{mg} / \mathrm{l}$ and a median of $13 \mathrm{mg} / \mathrm{l}$. Eighteen percent (18\%) of the total juice samples (apple juices and mixed juices) and twenty-eight percent (28\%) of the baby food samples exceeded the tolerable limit recommended by the European Union, which are respectively $50 \mathrm{mg} / \mathrm{l}$ and $10 \mathrm{mg} / \mathrm{l}$.

This study assessed contamination of foods by persistent organic pollutants (POPs) in the USA. Results showed that the highest level of pesticide contamination was from the dichlorodiphenyltrichloroethane (DDT) metabolite $p, p^{\prime}$ dichlorodiphenyldichloroethylene, which ranged from $0.028 \mathrm{ng} / \mathrm{g}$ wet weight (ww) in whole milk yogurt to $2.3 \mathrm{ng} / \mathrm{g} \mathrm{ww}$ in catfish fillets. Authors found polychlorinated biphenyls (PCB) congeners $(28,52,101,118,138,153$, and 180) primarily in fish, with highest levels in salmon (PCB153, $1.2 \mathrm{ng} / \mathrm{g}$ ww; PCB138, $0.93 \mathrm{ng} / \mathrm{g} \mathrm{ww}$ ). For PFCs, we detected perfluorooctanoic acid (PFOA) in 17 of 31 samples, ranging from $0.07 \mathrm{ng} / \mathrm{g}$ in potatoes to $1.80 \mathrm{ng} / \mathrm{g}$ in olive oil. In terms of dietary intake, DDT and DDT metabolites, endosulfans, aldrin, PCBs, and PFOA were consumed at the highest levels.

This study determined concentrations of copper and zinc in food items of various classes which were obtained from the markets of Nigeria. The results showed that copper levels ranged widely from 0.06 to $13.3 \mathrm{mg} / \mathrm{kg}$, while zinc levels ranged from 0.06 to $56.9 \mathrm{mg} / \mathrm{kg}$ in various foods. Highest levels of both metals were found to occur in legumes (Cu, $8.3 \pm 3.7 \mathrm{mg} /$ $\mathrm{kg} ; \mathrm{Zn}, 29 \pm 12 \mathrm{mg} / \mathrm{kg}$ ). The estimated weighted average dietary intakes for the entire adult population were calculated to be $2.64 \mathrm{mg} \mathrm{Cu} /$ day and $15.8 \mathrm{mg} \mathrm{Zn} /$ day.

This study assessed occurrence of volatile organic compounds (VOCs) in foods from the Belgian market. The results showed that the most prevalent OVCs and respective percentages of occurrence were as follows: chloroform (97\%), toluene (95\%), ethyl benzene (80\%), o-xylene (79\%), and benzene (58\%). The maximum probabilistic dietary intake was with 0.151 , $0.645,0.138,0.066$, and $0.118 \mathrm{mg} \mathrm{kg}$ bw 1 day 1 for chloroform, toluene, ethyl benzene, o-xylene, and benzene respectively.

This study assessed polybrominated diphenyl ether (PBDE) in retail fish and shellfish samples purchased from Canadian markets. The results showed that trout and salmon contain 1600 and $1500 \mathrm{pg} / \mathrm{g}$, wet weight, respectively. The concentration of PBDE was found to be 260,180 , and 48 $\mathrm{pg} / \mathrm{g}$, wet weight, respectively in mussel, tilapia, and shrimp.

Short communication This study determined cadmium and nickel composition of Nigerian foods. The results indicated that cadmium levels ranged from 0.01 to 0.62 $\mathrm{mg} / \mathrm{kg}$, with a general average of $0.16 \pm 0.14 \mathrm{mg} / \mathrm{kg}$. Cadmium levels varied significantly between different groups of foods, with the highest levels occurring in dairy $(0.41 \pm 0.25 \mathrm{mg} / \mathrm{kg})$, and the lowest in confectioneries and fruits $(0.07 \pm 0.04 \mathrm{mg} / \mathrm{kg})$. Nickel levels ranged from 0.05 to $9.22 \mathrm{mg} / \mathrm{kg}$ with a general average of $2.1 \pm 1.5 \mathrm{mg} / \mathrm{kg}$. The levels of both metals were found to be higher than the levels observed in similar foods in some developed countries.

This study assessed the level of heavy metals in Egyptian fruits and vegetables The results of this survey showed that the average concentrations detected were ranged from 0.01 to $0.87,0.01$ to $0.15,0.83$ 
Table 4 Summary of full-text articles which reported chemical contamination of foods as a public risk in food marketing (Continued)

\begin{tabular}{|c|c|c|c|}
\hline Authors & Country/region & Article type & Main message/findings \\
\hline & & & $\begin{array}{l}\text { to } 18.3 \text {, and } 1.36 \text { to } 20.9 \mathrm{mg} / \mathrm{kg} \text { for } \mathrm{Pb}, \mathrm{Cd}, \mathrm{Cu} \text {, and } \mathrm{Zn} \text {, respectively. The } \\
\text { highest mean levels of } \mathrm{Pb}, \mathrm{Cd}, \mathrm{Cu} \text {, and } \mathrm{Zn} \text { were detected in strawberries, } \\
\text { cucumber, date, and spinach, respectively. }\end{array}$ \\
\hline $\begin{array}{l}\text { Ali MH and Al-Qahtani KM, } \\
2012 \text { [45] }\end{array}$ & Saudi Arabia & Research article & $\begin{array}{l}\text { This study assessed concentration of heavy metals in vegetables, } \\
\text { cereals, and fruits in Saudi Arabian markets. The results declared that } \\
\text { concentrations of major studied metals were exceeding than the } \\
\text { recommended maximum acceptable levels proposed by the Joint FAO/ } \\
\text { WHO Expert Committee. Leafy vegetables were found to contain the } \\
\text { highest metal values especially parsley }(543.2 \text { and } 0.048 \mu \mathrm{g} / \mathrm{g} \text { for Fe and } \\
\mathrm{Hg} \text { respectively), Jews mallow }(94.12 \text { and } 33.22 \mu \mathrm{g} / \mathrm{g} \text { for Mn and } \mathrm{Zn} \\
\text { respectively), spinach ( } 4.13 \mu \mathrm{g} / \mathrm{g} \text { for } \mathrm{Cd}) \text {. While peas in legumes group } \\
\text { maintained the highest } \mathrm{Zn} \mathrm{content} 71.77 \mu \mathrm{g} / \mathrm{g} \text { and finally cucumber had } \\
\text { the highest Pb content } 6.98 \mu \mathrm{g} / \mathrm{g} \text { on dry matter basis. }\end{array}$ \\
\hline NIE Ji-yun, et al., 2016 & China & Research article & $\begin{array}{l}\text { This study analyzed the concentrations of the heavy in China's main } \\
\text { deciduous fruits. Only } 2.2 \% \text { of the samples were polluted by Ni, only } 0.4 \% \\
\text { of the samples were polluted by Pb, and no samples were polluted by } \mathrm{Cd} \\
\text { or Cr. For the combined heavy metal pollution, } 96.9 \% \text { of the samples } \\
\text { were at safe level, } 2.32 \% \text { at warning level, } 0.65 \% \text { at light level, and } 0.13 \% \\
\text { at moderate level. }\end{array}$ \\
\hline
\end{tabular}

Vinci RM, et al., 2012 [42] Belgium Research article

Moret S, et al., 2010 [46] Italy Research article

Ali Anma, 2013 [47]

Bangladesh

Regulatory paper

Hossain MM, et al., 2008 [48]
Bangladesh Research article
This study assessed human exposure to benzene through foods from the Belgian market. Benzene was found above the level of detection in 58\% of analyzed samples with the highest contents found in processed foods such as smoked and canned fish, and foods which contained these as ingredients (up to $76.21 \mathrm{\mu g} \mathrm{kg}^{-1}$ ).

This study assessed levels of polycyclic aromatic hydrocarbons (PAHs) in dietary supplements from the Italian market. The results showed that about half of the samples analyzed presented benzo[a]pyrene (BaP) concentrations exceeding $2 \mu \mathrm{g} / \mathrm{kg}$, which is proposed as a regulatory limit for dietary supplements.

This study investigated food safety and public health issues in Bangladesh. The study showed that use of formalin and DDT in foods is a crucial problem in Bangladesh. Supermarkets openly sell fruits, fishes, and vegetables that have been treated with formalin to keep them fresh. In Bangladesh, DDT is commonly used in dried fish (locally called as sutki) processing.

In this study, the following chemicals were found to be used in foods and foodstuffs: calcium carbide, sodium cyclamate, cyanide, urea (a nitrogenrelease fertilizer), and formalin. The sellers/producers mentioned the fol lowing reasons: for their use of harmful chemicals: to make the product more lucrative (40\%), to extend the product's shelf life (32\%), to substitute for unavailable natural raw materials (natural raw materials were not al ways available) (16\%), consumer demand $(8 \%)$, or because the adulterated raw materials were cheaper than natural goods (4\%). processing, packaging, transportation, and storage are significant contributors to food contamination [109]. Food contaminants include environmental contaminants, food processing contaminants, unapproved adulterants and food additives, and migrants from packaging materials. Environmental contaminants are impurities that are either introduced by human or occurring naturally in water, air, or soil. Food processing contaminants include those undesirable compounds, which are formed in the food during baking, roasting, canning, heating, fermentation, or hydrolysis. The direct food contact with packaging materials can lead to chemical contamination due to the migration of some harmful substances into foods. Use of unapproved or erroneous additives may result in food contamination [134-138]. Chemical contamination of foods is responsible millions of cases of poisoning with thousands of hospitalizations and deaths each year [139].

Nine of the full-text articles included in this review reported that food adulteration is a major public health risk associated with food safety issues in the food market. Chemicals, items which are not the genuine component of foods, poor-quality products, and physical or inert agents are the commonest adulterants added [47, 49-56]. Food adulteration involves intentional or unintentional addition of useless, harmful, unnecessary chemical, physical, and biological agents to food which decreases the quality of food. It also includes removal of genuine components and processing foods in unhygienic way $[119,140]$. However, removal of genuine components of food is not considered in this review. Food is adulterated to increase the quantity 
Table 5 Summary of full-text articles which reported food adulteration as a public risk in food marketing

\begin{tabular}{|c|c|c|c|}
\hline Authors & $\begin{array}{l}\text { Country/ } \\
\text { region }\end{array}$ & Article type & Main message/findings \\
\hline Ali Anma, 2013 [47] & Bangladesh & $\begin{array}{l}\text { Regulatory } \\
\text { paper }\end{array}$ & $\begin{array}{l}\text { This study investigated food safety and public health issues in Bangladesh. The study } \\
\text { pointed out that most of the foodstuffs, be it manufactured or processed, are } \\
\text { adulterated in varying degrees. The puffed rice is contaminated by using the urea } \\
\text { fertilizer to make it whiter and bigger in size. Ghee is adulterated rotten milk, palm } \\
\text { oil, soybean, animal or vegetable fat, potato paste, and with artificial color flavors. }\end{array}$ \\
\hline $\begin{array}{l}\text { Nasreen S and Ahmed T, } \\
2014 \text { [49] }\end{array}$ & Bangladesh & Research article & $\begin{array}{l}\text { This study investigated the magnitude of food adulteration during 1995-2011 } \\
\text { and consumer awareness in Dhaka City. The study reported that 40-54\% of daily- } \\
\text { consumed food was adulterated during 1995-2011. More than } 35 \text { food items were } \\
\text { commonly adulterated. Some of the hazardous adulterants were white eggs of farm } \\
\text { hens colored red with textile dye to sell as local hen eggs; inject formalin through } \\
\text { the gills; or dip fishes in water treated with chemicals, such as chlorofluorocarbon; } \\
\text { DDT powder to prevent rotting; textile dye in sweetened curd; toxic chemical, po } \\
\text { tato smash, cow's fat and intestine in ghee; chemicals, color, burnt mobil from rail } \\
\text { locomotives, and burnt oil from electric transformer in edible oils; urea in rice to } \\
\text { make it whiter; and many more others. }\end{array}$ \\
\hline
\end{tabular}

Chanda T, et al., 2012 [50] Bangladesh Research article This study aimed to detect the type of adulterants and preservatives added to the incoming fluid milk from rural areas to the Barisal, Bangladesh. The results indicated that $100 \%$ of the milk samples were adulterated with water. Cane sugar, powdered milk, and starch were detected as 26.0, 14.0, and $12.0 \%$ in the milk samples, respectively. Out of all samples, $10.0 \%$ was adulterated with formalin and $20.0 \%$ with sodium bicarbonate.

Singuluri $\mathrm{H}$ and Sukumaran $\mathrm{M}$, India 2014 [51]

Barham GS, et al., 2014 [52] Pakistan

Waghray K, et al., 2011 [53] India

Peng G-J, et al., 2017 [54]

Taiwan

Research article

Ethiopia

Woldemariam HW and

Abera BD, 2014 [55]

Assefa A, et al., 2013 [56]

Research article
The study assessed adulteration of natural milk with various illegal substances. The results pointed out that sucrose and skim milk powder were present in 22\% and $80 \%$ of the milk samples respectively. Urea, neutralizers, and salt were present in $60 \%$, $26 \%$, and $82 \%$ of the milk samples respectively. Formalin, detergents, and hydrogen peroxide were present in 32\%,44\%, and 32\% of the milk samples obtained.

Research article This study examined various adulterants of milk in Pakistan. The study found that water $(73 \%)$, detergent $(32 \%)$, cane sugar $(22 \%)$, caustic soda $(20 \%)$, rice flour $(17 \%)$, sodium chloride and skimmed milk powder (15\%), hydrogen peroxide (13\%), starch $(12 \%)$, formalin (11\%), urea and vegetable oil (10\%), boric acid (8\%), ammonium sulfate (6\%), glucose (5\%), sorbitol (4\%), and arrowroot (1\%) were found in milk samples.

Research article This study identified the adulteration in different food products available in the twin cities of Hyderabad and Secunderabad. The findings showed that chili powder samples showed the presence of metanil yellow (8\%) added color (92\%) and saw dust (48\%). Dry ginger samples (8.33\%) showed the presence of an unpermitted colored dye ultramarine blue. The sweet meat samples showed the presence of aluminum foil (4.3\%) instead of silver foil. Coconut burfi samples contained unpermitted color orange II and cotton candy and floss candy showed the presence of rhodamine B. The total percentage of adulteration in the food samples was found to be $49.41 \%$.

This study outlines the major cases of food adulteration that occurred in Taiwan between 2011 and 2015, including the adulteration of food additives with plasticizers, starch products with maleic anhydride, olive oil with copper chlorophyll, lard with recycled cooking oil, and processed soymilk curd with dimethyl/diethyl yellow.

Research article This study investigated the extent of adulteration of selected foods in Bahir Dar, Ethiopia. The result showed that $6.7 \%$ of butter samples were adulterated with vegetable sources, mainly mashed potatoes; $8 \%$ of coffee powder samples were adulterated with roasted cereals; $15 \%$ of honey samples were adulterated with sugar or invert sugar; $1.3 \%$ of the red pepper powder samples were adulterated with brick powder; and $2.7 \%$ of edible oil samples contain argemone oil.

Ethiopia Research article This study investigated the causes of dropsy in Addis Ababa, Ethiopia. The result indicated that 47 of the 280 edible oils analyzed were adulterated with argemone oil. and make more profit, which is economically motivated adulteration [141-143]. Chemicals which are being used as adulterants have a wide range of serious effects on the health of consumers including cancer [119, 144-147].

In this systematic review of literature, 11 of the fulltext articles reported that misuse of food additives in the food market endangers public health [57-67]. Food additive is any substance not normally consumed as a food by itself; not normally used as a typical ingredient of the food (whether or not it has nutritive value); and added intentionally to food for a technological purpose in the production process for the purpose of maintaining 
Table 6 Summary of full-text articles which reported misuse of food additives as a public risk in food marketing

\begin{tabular}{llll}
\hline Authors & $\begin{array}{l}\text { Country/ } \\
\text { region }\end{array}$ & Article type & Main message/findings \\
\hline Dixit S, et al., 2011 [57] & India & $\begin{array}{l}\text { Research } \\
\text { article }\end{array}$ & $\begin{array}{l}\text { This study assessed usage pattern of synthetic food colors in different states of India. The results } \\
\text { revealed that the majority of candyfloss, sugar toys, beverages, mouth fresheners, ice candy, } \\
\text { and bakery product samples exceeded the prescribed limit. Non-permitted colors were mostly } \\
\text { prevalent in candyfloss and sugar toy samples. Though sunset yellow FCF (SSYFCF) and } \\
\text { tartrazine were the two most popular colors, many samples used a blend of two or more } \\
\text { colors. The blend of SSYFCF and tartrazine exceeded the prescribed limit by a factor of } 37 \text { in } \\
\text { one sample. }\end{array}$
\end{tabular}

Tripathi M, et al., India Research This study assessed use of synthetic colors in India. The study reported that 31\% samples 2007 [58] article contained non-permitted colors. In urban areas, samples of crushed ice which are preferentially consumed by children population, the presence of Sunset Yellow FCF and Tartrazine was found to exceed the permissible limit by 8 and 20 times while in rural areas, Sunset Yellow FCF, Tartrazine, and Carmoisine exceeded the permissible limit by 23, 16, and 15 times, respectively. Non-permitted colors such as rhodamine B, metanil yellow, orange II, malachite green, auramine, quinoline yellow, amaranth, and Sudan dyes were identified in various foodstuffs.

Stevens $L$, et al., 2014 [59]

Rao P, et al., 2004 [60]

India

Ashfaq N and Masud T, Pakistan 2002 [61]

Jonnalagadda PR, et al., 2004 [62]

Tsai C-F, et al., 2015 [63] Taiwan

Moradi-Khatoonabadi Z, Iran et al., 2015 [64]

Saleem $N$ and Umar ZN, 2013 [65]

\section{Pakistan Research}

article

Petigara Harp B, et al., 2013 [66]

Research article

Sood M, 2014 [67]

Research article

Research article

Research article

Research article

Indonesia Field quinoline yellow, and sunset yellow, with $44 \%, 9.1 \%$, and $8.4 \%$ of the samples testing positive for these colors, respectively. Carmoisine and ponceau were both detected only in $0.5 \%$ of the positive samples and found only in saffron solution.

This study assessed the type of food colors added to various food products especially those vended at or near different educational institutes of Karachi City, Pakistan. The results revealed that some foods manufactured locally contained non-permitted colors. About $11 \%$ branded and $44 \%$ unbranded food items, respectively, were found with not permitted colors for human consumption. Similarly, $4 \%$ branded and $30 \%$ unbranded beverages were found unfit due to the presence of prohibited colors.

This survey assessed color additives in food products purchased from retail stores in Washington, DC, and surrounding Maryland counties. A survey of 44 food products, including beverages, frozen treats, powder mixes, gelatin products, candies, icings, jellies, spices, dressings, sauces, baked goods, and dairy products, found total color additives ranging from 1.9 to 1221 $\mathrm{mg} / \mathrm{kg}$. inspection
This field inspection on imported processed food products in Indonesia found processing food products that are not in accordance with the provisions. Some processing food products contain harmful substances such as formaldehyde, rhodamine B, saccharin, benzoic acid, methanol, yellow, and cyclamate, and preservatives and other harmful dyes. 
Table 7 Summary of full-text articles which reported mislabeling as a public risk in food marketing

\begin{tabular}{|c|c|c|c|}
\hline Authors & Country/region & Article type & Main message/findings \\
\hline $\begin{array}{l}\text { Miller DD and Mariani S, } \\
2010 \text { [68] }\end{array}$ & Ireland & Research article & $\begin{array}{l}\text { This study collected food samples from supermarkets, shops, and restaurants } \\
\text { Dublin, Ireland to assess labeling and transparency in the European seafood } \\
\text { industry. The assessment showed that } 39 \text { out of } 156(25 \%) \text { samples were } \\
\text { genetically identified as entirely different species from that identified on the } \\
\text { product labels, and therefore were considered as mislabeled. More significant } \\
28 \text { out of } 34(82.4 \%) \text { smoked fish samples were found to be mislabeled. }\end{array}$ \\
\hline $\begin{array}{l}\text { Jacquet JL and Pauly D, } \\
2008 \text { [69] }\end{array}$ & USA & Research article & $\begin{array}{l}\text { This paper examines the extent and consequences of renaming and mislabeli } \\
\text { seafood, with particular attention to the USA, where } 80 \% \text { of the seafood is } \\
\text { imported and more than one-third of all fish are mislabeled. }\end{array}$ \\
\hline Armani A, et al., 2012 & Italy & Research article & $\begin{array}{l}\text { This survey assessed label compliance of jellyfish products sold on the Italian } \\
\text { market. The survey found many shortfalls including the presence of a trade } \\
\text { name referring to vegetables or a lack of an unequivocal specification of } \\
\text { ingredients. }\end{array}$ \\
\hline
\end{tabular}

Armani A, et al., $2013 \quad$ Italy and China Research article

Chin TC, et al., 2016 [70] Malaysia

Nagalakshmi K, et al., India 2016 [71]

Galal-Khallaf A, et al., 2014 [72]

Cawthorn D-M, et al, 2012 [73]

Di Pinto A, et al., 2015 [74]

Carvalho DC, et al., 2017 [75]

Garcia-Vazquez E, et al., 2010 [76]

Staffen CF, et al., 2017 [77]

Muñoz-Colmenero M, et al., 2017 [78]

Muñoz-Colmenero M, 2016 [79]

Research article

Research article

Research article

Egypt

South Africa

Research article

Research article

Spain and Greek Research article

Brazil Research article

Spain, USA, and Research article Canada

Research article
Forensically informative nucleotide sequencing (FINS) of a short mitochondrial COI gene fragment revealed $100 \%$ of the sample of ready-to-eat jellyfish food products in Italy and China were mislabeled.

This study detected mislabeled seafood products in Malaysia by DNA barcoding. A total of 62 seafood samples, either raw, frozen, or variously processed, were collected from commercial sources in Malaysia. The DNA targets were successfully amplified and sequenced from $81 \%$ of seafood samples. Among these samples, $16 \%$ were found to have been mislabeled at source.

This study found out the level of seafood mislabeling prevailing in India using DNA barcoding. A total of 100 seafood samples including fresh, frozen, ready-tocook, ready-to-eat, and canned products were collected. The results revealed 22\% of seafood mislabeling prevailing in Indian domestic market.

This study assessed the labeling status of Egyptian fish fillets. DNA barcoding was applied to ascertaining species in fish fillets (tilapia, Nile perch, and panga) purchased from Egyptian markets. Ninety commercial samples were analyzed. Sequencing of a short fragment of mitochondrial cytochrome oxidase I (COI) gene revealed $33.3 \%$ species substitution in the fish fillets analyzed, 50\% Nile perch (Lates niloticus) and 50\% basa fish (Pangasius bocourti) being replaced by imported Vietnamese tra fish (Pangasianodon hypophthalmus).

This study investigated incidence of fish species misrepresentation and substitution on the South African market. The results showed that 10 of 108 (9\%) samples from wholesalers and 43 of 140 (31\%) from retailers were identified as different species to the ones indicated at the point of sale.

This study investigated processed-meat products from Italian markets in order to verify any species substitution or mislabeling. The results revealed a high substitution rate among the meat products, highlighting a mislabeling rate of $57 \%$, and consequently, considerable discordance with the indications on the labels.

Research article This study analyzed twenty-two processed cod products purchased from supermarkets, local stores, fast food outlets, and one restaurant in the city of Belo Horizonte, Brazil. A mixture of two or more species was found within 31\% of all products and $41 \%$ mislabeling was reported within highly processed cod products.

DNA analysis of hake products commercialized in Spanish and Greek market chains has demonstrated more than 30\% mislabeling, on the basis of species substitution. Tails and fillets were more mislabeled than other products, such as slices and whole pieces. African species were substitute species for products labeled as American and European species.

This study assessed labeling of fish products in a popular tourist destination in Brazil. A DNA barcoding of 65 samples from fisheries and 80 from restaurants revealed that $30 \%$ of mislabeled samples in fisheries and $26 \%$ in restaurants.
This study assessed mislabeling in salmon products from two regions, Northwest of America and Northwest of Spain. A DNA barcoding of samples indicated that the Spanish and Northwest American samples were mislabeled 6\% and $23.8 \%$ respectively.

This study authenticated the species of fish marketed in Spain. DNA sequences of 245 fish samples revealed greater than 7\% mislabeling. 
Table 7 Summary of full-text articles which reported mislabeling as a public risk in food marketing (Continued)

\begin{tabular}{llll}
\hline Authors & Country/region & Article type & Main message/findings \\
\hline Bosko SA, et al., 2018 [80] & USA & Research article & $\begin{array}{l}\text { This study tested } 80 \text { catfish samples collected from restaurants, grocery stores, } \\
\text { and fish markets in the USA tested with real-time PCR. A DNA barcoding of } \\
\text { samples showed that } 7 \text { of the } 80 \text { catfish products were found to be substituted }\end{array}$ \\
& & $\begin{array}{l}\text { with Pangasiidae species for a mislabeling rate of 9\%. This included } 5 \text { of the } 40 \\
\text { restaurant samples and } 2 \text { of the } 32 \text { grocery store samples. }\end{array}$
\end{tabular}

Christiansen $\mathrm{H}$, et al., Belgium $\quad$ Research article This study assessed seafood substitution and mislabeling in Brussels' restaurants 2018 [81] and canteens. A DNA barcoding revealed that $31.1 \%$ of the samples were mislabeled, with mislabeling present in all types of vendors. Cod and sole were the most frequently sampled and were also mislabeled regularly $(13.1 \%$ and $11.1 \%)$. Bluefin tuna was substituted almost always (95\% mislabeling).

Galal-Khallaf A, et al., $\quad$ Egypt and Spain Research article 2002 [82]

This study is a PCR-based assessment of shellfish traceability and sustainability in seafood markets. The results found that $17.2 \%$ and $15.2 \%$ products were mis labeled in Egypt and Spain, respectively.

a food's nutritional quality, for example by preventing the degradation of vitamins, essential amino acids, and unsaturated fats; extending the shelf life of a product, for example by preventing microbial growth; and maintaining and improving a product's sensory properties, such as texture, consistency, taste, flavor, and color; Being able to provide products $[148,149]$. Substances generally recognized as safe (GRAS) can be used as food additives $[150,151]$; however, misuse of substances such as using more than the maximum allowable concentration; using non-permitted substances; and blending of permitted and non-permitted substances together causes health hazards $[152,153]$.
Mislabeling of food products has been mentioned as a major public health risk associated with food safety in the food market in 17 of the full-text articles included in this review [68-82, 154]. Mislabeling of food products includes false advertising, deliberately or accidentally leaving out ingredients, not listing potential health effects, and claiming a food contains ingredients that it does not for financial gain with the intent of deceiving the consumer regarding what is actually in the package [155]. These acts of fraud have increased overtime as different parties such as manufacturers, co-packers, distributors, and others along the chain of distribution involve in the national or international trade. Mislabeling leads

Table 8 Summary of full-text articles which reported genetically modified foods as a public risk in food marketing

\begin{tabular}{|c|c|c|c|}
\hline Authors & Country/region & Article type & Main message/findings \\
\hline $\begin{array}{l}\text { Swanson NL, et al., } \\
2014 \text { [83] }\end{array}$ & USA & Research article & $\begin{array}{l}\text { This study found that the Pearson correlation coefficients are highly significant } \\
\left(<10^{-4}\right) \text { between the percentage of GE corn and soy planted in the USA and } \\
\text { hypertension }(R=0.961) \text {, stroke }(R=0.983) \text {, diabetes prevalence }(R=0.983) \text {, } \\
\text { diabetes incidence }(R=0.955) \text {, obesity }(R=0.962) \text {, lipoprotein metabolism } \\
\text { disorder }(R=0.955) \text {, Alzheimer's }(R=0.937) \text {, Parkinson's ( } R=0.952) \text {, multiple } \\
\text { sclerosis }(R=0.876) \text {, hepatitis } C(R=0.946) \text {, end-stage renal disease }(R=0.958) \text {, } \\
\text { acute kidney failure }(R=0.967) \text {, cancers of the thyroid }(R=0.938) \text {, liver }(R= \\
\text { 0.911), bladder }(R=0.945) \text {, pancreas }(R=0.841) \text {, kidney }(R=0.940) \text {, and myeloid }\end{array}$ \\
\hline
\end{tabular}

Pattron DD, 2005 [84] Eastern Research article

Caribbean

Bakshi A, 2003 [85]

General setting

Research article

Aris A and Leblanc S, Canada 2011 [86] leukemia $(R=0.889)$.

This study investigated health implications associated with GM foods in Trinidad. The survey found that diarrhea, vomiting, rashes, difficulty in breathing, respiratory problems, hormonal imbalances, and susceptibility to infection or immunosuppression are common reported health problems associated with consuming GM foods. These medical claims were supported by medical certificates, diagnosis, treatment regimens, and physician letters and/or prescriptions. Foods consumed were validated against the list of known genetically modified foods

There are concerns about the safety of genetically modified crops. The concerns are that they may contain allergenic substances due to introduction of new genes into crops. Another concern is that genetic engineering often involves the use of antibiotic-resistance genes as "selectable markers" and this could lead to production of antibiotic-resistant bacterial strains that are resistant to available antibiotics. This would create a serious public health problem. The genetically modified crops might contain other toxic substances (such as enhanced amounts of heavy metals).

This study highlighted the presence of pesticide-associated genetically modified foods in maternal, fetal, and non-pregnant women's blood in Quebec, Canada. 3MPPA and Cry1 Ab toxins are clearly detectable and appear to cross the placenta to the fetus. 
Table 9 Summary of full-text articles which reported foods past their use-by dates as a public risk in food marketing

\begin{tabular}{|c|c|c|c|}
\hline Authors & Country/region & Article type & Main message/findings \\
\hline $\begin{array}{l}\text { Anyanwu RC and } \\
\text { Jukes DJ, } 1991 \text { [87] }\end{array}$ & Nigeria & Research article & $\begin{array}{l}\text { This study assessed food systems and food control in Nigeria. The results showed } \\
\text { that foods are very poorly handled in the rural food system, with expired food } \\
\text { being sold. }\end{array}$ \\
\hline Burnett K, et al., 2015 [88] & Canada & Research article & $\begin{array}{l}\text { This is an online survey gathered community input about retail and food } \\
\text { purchasing experiences in northern Canada. Preliminary findings show that } \\
\text { expired foods are of the top three concerns of food safety. Eighty-two percent } \\
\text { stated that their store often or sometimes sold expired food. }\end{array}$ \\
\hline $\begin{array}{l}\text { Freedman DA and Bell BA, } \\
2009 \text { [89] }\end{array}$ & USA & Research article & $\begin{array}{l}\text { This study investigated access to foods among an urban food insecure } \\
\text { population in Nashville, USA. In this study, } 10 \text { of } 37(27 \%) \text { of the participants } \\
\text { reported that food stores in their neighborhood sell outdated foods. }\end{array}$ \\
\hline Sood M, 2014 [67] & Indonesia & Field inspection & $\begin{array}{l}\text { This field inspection on imported processed food products in Indonesia found } \\
\text { processing food products that are not in accordance with the provisions. Expired } \\
\text { food products are found sold in various markets, such as supermarkets, shops, } \\
\text { and traditional markets, such products also circulated illegally entered and } \\
\text { especially to the areas that have access to transportation that are difficult to } \\
\text { reach. }\end{array}$ \\
\hline Islam M, 2017 [36] & Bangladesh & Thesis & $\begin{array}{l}\text { This study assessed bacteriological quality of street-vended and expired food } \\
\text { items collected from different areas in Dhaka City, Bangladesh. Out of total } 35 \\
\text { food samples (expired and street), enteric bacteria were found in } 17 \text { (48.6\%) food } \\
\text { samples containing E. coli, Vibrio, Shigella, and Salmonella species. }\end{array}$ \\
\hline $\begin{array}{l}\text { Kunyanga C, et al., } \\
2011 \text { [90] }\end{array}$ & Kenya & Research article & $\begin{array}{l}\text { This study assessed characteristics of foods sold and consumed by vulnerable } \\
\text { groups in Kenya. The study reported that it was possible for consumers to } \\
\text { continue using the foods even after they had expired and were no longer able to } \\
\text { meet the nutrition and health requirements at the levels declared on the labels. }\end{array}$ \\
\hline
\end{tabular}

to cross-contamination, poor food quality, degradation of nutrients, and even adverse effects on human health, serious financial, and legal consequences [69, 154].

In this systematic review, we identified that GM foods are becoming an increasing public health risk. The included full-text articles reported that a wide range of health consequences associated with consumption of GM foods [83-86]. Possible hazards of GM foods include the potential for pleiotropic and insertional effects (silencing of genes, changes in their level of expression or, potentially, the turning on of existing genes that were not previously being expressed), effects on animal and human health resulting from the increase of anti-nutrients, potential effects on human health resulting from the use of viral DNA in plants, possible transfer of antibiotic-resistant genes to bacteria in gastrointestinal tract, and possible effects of GM foods on allergic responses [156-161]. However, the health effects of genetically modified foods are still debatable. Different lab-animal-based studies reported that there is no safety difference between GM and nonGM foods or the health concerns are not confirmed well [162-165]. Some others argue that despite the advances in food crop agriculture, the current world situation is still characterized by massive hunger and chronic malnutrition, representing a major public health problem. Biofortified GM crops have been considered an important and complementary strategy for delivering naturally fortified staple foods to malnourished populations [164].

This review revealed that foods past their use-by dates in the food market are major threats for consumers. This malpractice is more common in less developed countries and rural markets [36, 67, 87-90]. Growth of microorganisms in expired foods is very common. Most of these microorganisms are pathogenic and some microorganisms produce toxic substances as they develop [36, 121, 166-169].

\section{Limitation of the review}

We entirely relied on electronic databases to search relevant articles. We did not include articles available in hard copy. We believed we could get more relevant articles if we had access to hard prints.

\section{Conclusion}

This systematic literature review identified common food safety-related public health risks in the food market. The results imply that the local and international food marketing continues to have significant impacts on health of the public. The food market increases internationalization of health risks as the food supply chains cross multiple national borders. Therefore, effective national food control systems are essential to protect the health and safety of the public. Countries have to implement and enforce risk-based food control strategies. Countries need also assure the safety and quality of their foods entering international trade and ensure that imported foods conform to national requirements. Moreover, food producers and retail sectors have to respect the national food safety guideline and have to work to protect the safety of their customers Additional file 1. 


\section{List of full text articles included in the review} The full text articles included in this review are attached as a supplementary file (see supplementary file).

\section{Supplementary information}

Supplementary information accompanies this paper at https://doi.org/10. 1186/s12199-019-0825-5.

Additional file 1. List of full text articles included in the review.

\section{Abbreviations}

DALYs: Disability adjusted life years; GM: Genetically modified foods; GRAS: Substances generally recognized as safe; JBI: Joanna Briggs Institute; MMAT: Mixed methods appraisal tool; PICo: Population, phenomena of interest, and context

\section{Acknowledgements}

The author would like to thank The Ohio State University Health Science Library for helping him to access different electronic databases.

\section{Author's contribution}

The authors read and approved the final manuscript.

\section{Funding}

The author of this review did not receive funds from any funding institution.

\section{Availability of data and materials}

All the extracted data are included in the manuscript.

\section{Ethics approval and consent to participate}

Not applicable for systematic reviews.

\section{Consent for publication}

This manuscript does not contain any individual person's data.

\section{Competing interests}

The author declares that he has no competing interests.

Received: 13 August 2019 Accepted: 16 October 2019 Published online: 30 November 2019

\section{References}

1. Uyttendaele M, Franz E, Schlüter O. Food safety, a global challenge. Int J Environ Res Public Health. 2016;13(1):67. https://doi.org/10.3390/ ijerph13010067.

2. Radovanovic R. Food safety: the global problem as a challenge for future initiatives and activities. Advances in Food Protection: Springer; 2011. p. 2748.

3. World Health Orgnization (WHO). Food safety fact sheet, 04 June 2019 Available at https://www.who.int/news-room/fact-sheets/detail/food-safety. Accessed on 06 Aug 2019.

4. Hawkes C. Uneven dietary development: linking the policies and processes of globalization with the nutrition transition, obesity and diet-related chronic diseases. Global Health. 2006;2(1):4.

5. Athukorala PC, Jayasuriya S. Food safety issues, trade and WTO rules: a developing country perspective. World Econ. 2003:26(9):1395-416.

6. Negri S. Food safety and global health: an international law perspective. Global Health Governance. 2009:3(1).

7. Kruse $\mathrm{H}$. Food safety in an international perspective. J. Verbr. Lebensm 2015;10:105-7. https://doi.org/10.1007/s00003-015-0948-6.

8. Spink J, Moyer DC. Defining the public health threat of food fraud. J Food SC. 2011;76(9):R157-R63.

9. Van Schothorst M. Microbiological risk assessment of foods in international trade. Safety Sci. 2002;40(1-4):359-82.

10. Mathews KH Jr, Bernstein J, Buzby JC. International trade of meat/poultry products and food safety issues. Int Trade Food Safety. 2003;AER-828:48-73.

11. Lang T. The new globalisation, food and health: is public health receiving its due emphasis? J Epidemiol Commun Health. 1998;52(9):538.
12. Aung MM, Chang YS. Traceability in a food supply chain: safety and quality perspectives. Food Control. 2014;39:172-84.

13. Wu F. Global impacts of aflatoxin in maize: trade and human health. World Mycotoxin J. 2014:8(2):137-42.

14. Bryden WL. Mycotoxins in the food chain: human health implications. Asia Pacific J Clin Nutr. 2007:16(S1):95-101.

15. Hong QN, Pluye P, Fàbregues S, Bartlett G, Boardman F, Cargo M, et al. Mixed methods appraisal tool (MMAT), version 2018. Registration of Copyright (\#1148552), Canadian Intellectual Property Office, Industry Canada. Available at http://mixedmethodsappraisaltoolpublic.pbworks.com/. Accessed on 08 July 2019.

16. JBI mixed methods data extraction form following a convergent integrated approach. Available at https://wiki.joannabriggs.org/display/MANUAL/ Appendix+8.1+JBl+Mixed+Methods+Data+Extraction+Form+following+a+ Convergent+Integrated+Approach. Accessed on 12 July 2019

17. Rhodehamel EJ. Overview of Biological, Chemical, and Physical Hazards. In: Pierson MD, Corlett DA, editors. HACCP. Springer Link, Boston. 1992; pp 8-28.

18. Adeyanju GT, Ishola O. Salmonella and Escherichia coli contamination of poultry meat from a processing plant and retail markets in Ibadan, Oyo State, Nigeria. Springerplus. 2014;3(1):139.

19. Giammanco GM, Pepe A, Aleo A, D'Agostino V, Milone S, Mammina C. Microbiological quality of Pecorino Siciliano "primosale" cheese on retail sale in the street markets of Palermo, Italy. 2011;34(2):New Microbiologica, 179-85.

20. Zhao C, Ge B, De Villena J, Sudler R, Yeh E, Zhao S, et al. Prevalence of Campylobacter spp., Escherichia coli, and Salmonella serovars in retail chicken, turkey, pork, and beef from the Greater Washington, DC, area. Appl Environ Microbiol. 2001;67(12):5431-6.

21. Cárdenas C, Molina K, Heredia N, García S. Evaluation of microbial contamination of tomatoes and peppers at retail markets in Monterrey, Mexico. J Food Protect. 2013;76(8):1475-9.

22. Filiousis G, Johansson A, Frey J, Perreten V. Prevalence, genetic diversity and antimicrobial susceptibility of Listeria monocytogenes isolated from openair food markets in Greece. Food Control. 2009;20(3):314-7.

23. Pérez-Rodríquez F, Castro R, Posada-Izquierdo G, Valero A, Carrasco E, García-Gimeno R, et al. Evaluation of hygiene practices and microbiological quality of cooked meat products during slicing and handling at retail. Meat Science. 2010:86(2):479-85.

24. Yagoub SO. Isolation of Enterobacteriaceae and Pseudomonas spp. from raw fish sold in fish market in Khartoum state. Afr J Bacteriol Res. 2009;1 (7):085-8.

25. Kumari S, Sarkar PK. Prevalence and characterization of Bacillus cereus group from various marketed dairy products in India. Dairy Sci Technol. 2014;94(5): 483-97.

26. Domınguez C, Gomez I, Zumalacarregui J. Prevalence of Salmonella and Campylobacter in retail chicken meat in Spain. International Journal of Food Microbiology. 2002;72(1-2):165-8.

27. Vantarakis A, Affifi M, Kokkinos P, Tsibouxi M, Papapetropoulou M. Occurrence of microorganisms of public health and spoilage significance in fruit juices sold in retail markets in Greece. Anaerobe. 2011;17(6):288-91.

28. Heredia N, Garcia S, Rojas G, Salazar L. Microbiological condition of ground meat retailed in Monterrey, Mexico. Journal of food protection. 2001;64(8): 1249-51.

29. Elson R, Burgess F, Little C, Mitchell R. Services LACooR, Agency tHP. Microbiological examination of ready-to-eat cold sliced meats and pâté from catering and retail premises in the UK. J Appl Microb. 2004;96(3):499-509.

30. Hosseini A. The prevalence of bacterial contamination of table eggs from retails markets by Salmonella spp., Listeria monocytogenes, Campylobacter jejuni and Escherichia coli in Shahrekord, Iran. Jundishapur J Microbiol 2011 4(4):249.

31. Banerjee M, Sarkar PK. Microbiological quality of some retail spices in India. Food Res Int. 2003:36(5):469-74

32. Vindigni SM, Srijan A, Wongstitwilairoong B, Marcus R, Meek J, Riley PL, et al. Prevalence of foodborne microorganisms in retail foods in Thailand. Foodborne Pathogens Disease. 2007:4(2):208-15

33. Simforian $\mathrm{E}$, Nonga $\mathrm{H}$, Ndabikunze $\mathrm{B}$. Assessment of microbiological quality of raw fruit juice vended in Dar es Salaam City, Tanzania. Food Control. 2015:57:302-7.

34. Mailafia S, God'spower Richard Okoh HO, Olabode K, Osanupin R. Isolation and identification of fungi associated with spoilt fruits vended in Gwagwalada market, Abuja, Nigeria. Veterinary world. 2017;10(4):393. 
35. Hunter PR, Hornby H, Campbell CK, Browne KF. Isolation of food spoilage yeasts from salads purchased from delicatessens. British Food J. 1994;96(3):23-5.

36. Islam M. Study on bacteriological quality of street-vended and expired food items collected from different areas in Dhaka City. Bangladesh: East West University; 2017

37. Bai $Y$, Zhou L, Wang J. Organophosphorus pesticide residues in market foods in Shaanxi area, China. Food Chem. 2006;98(2):240-2.

38. Othman ZAA. Lead contamination in selected foods from Riyadh City market and estimation of the daily intake. Molecules. 2010;15(10):7482-97.

39. Zaied C, Abid S, Hlel W, Bacha H. Occurrence of patulin in apple-basedfoods largely consumed in Tunisia. Food Control. 2013;31(2):263-7.

40. Schecter A, Colacino J, Haffner D, Patel K, Opel M, Päpke O, et al. Perfluorinated compounds, polychlorinated biphenyls, and organochlorine pesticide contamination in composite food samples from Dallas, Texas, USA. Environmental health perspectives. 2010;118(6):796-802.

41. Onianwa P, Adeyemo A, Idowu O, Ogabiela E. Copper and zinc contents of Nigerian foods and estimates of the adult dietary intakes. Food Chem. 2001; 72(1):89-95

42. Vinci RM, Jacxsens $L$, De Meulenaer B, Deconink E, Matsiko E, Lachat C, et al. Occurrence of volatile organic compounds in foods from the Belgian market and dietary exposure assessment. Food Control. 2015;52:1-8.

43. Tittlemier SA, Forsyth D, Breakell K, Verigin V, Ryan JJ, Hayward S. Polybrominated diphenyl ethers in retail fish and shellfish samples purchased from Canadian markets. J Agricult Food Chem. 2004;52(25):7740-5.

44. Radwan MA, Salama AK. Market basket survey for some heavy metals in Egyptian fruits and vegetables. Food Chem Toxicol. 2006;44(8):1273-8.

45. Ali MH, Al-Qahtani KM. Assessment of some heavy metals in vegetables, cereals and fruits in Saudi Arabian markets. Egypt J Aquatic Res. 2012;38(1):31-7.

46. Moret S, Purcaro G, Conte LS. Polycyclic aromatic hydrocarbons (PAHs) levels in propolis and propolis-based dietary supplements from the Italian market. Food Chem. 2010;122(1):333-8.

47. Ali ANMA. Food safety and public health issues in Bangladesh: a regulatory concern. Eur Food Feed Law Rev. 2013:31-40.

48. Hossain MM, Heinonen V, Islam KZ. Consumption of foods and foodstuffs processed with hazardous chemicals: a case study of Bangladesh. Int J Consum Stud. 2008;32(6):588-95.

49. Nasreen S, Ahmed T. Food adulteration and consumer awareness in Dhaka City, 1995-2011. Journal of health, population, and nutrition. 2014;32(3):452.

50. Chanda T, Debnath G, Hossain M, Islam M, Begum M. Adulteration of raw milk in the rural areas of Barisal district of Bangladesh. Bangladesh J Anim Science. 2012;41(2):112-5.

51. Singuluri $H$, Sukumaran M. Milk adulteration in Hyderabad, India-a comparative study on the levels of different adulterants present in milk. J Chromatogr Sep Techn. 2014;5(1):1.

52. Barham GS, Khaskheli M, Soomro AH, Nizamani ZA. Extent of extraneous water and detection of various adulterants in market milk at Mirpurkhas, Pakistan. J Agri Vet Sci. 2014;7(3):83-9.

53. Waghray K, Gulla S, Thyagarajan P, Vinod G. Adulteration pattern in different food products sold in the twin cities of Hyderabad and Secunderabad-India. Journal of Dairying Foods \& Home Sciences. 2011;30(2)

54. Peng G-J, Chang M-H, Fang M, Liao C-D, Tsai C-F, Tseng S-H, et al. Incidents of major food adulteration in Taiwan between 2011 and 2015. Food Control. 2017;72:145-52.

55. Woldemariam HW, Abera BD. The extent of adulteration of selected foods at Bahir Dar, Ethiopia. Int J Interdisciplin Res. 2014;1(6):1-6.

56. Assefa A, Teka F, Guta M, Melaku D, Naser E, Tesfaye B, et al. Laboratory investigation of epidemic dropsy in Addis Ababa, Ethiopia. Ethiop Med J. 2013:21-32.

57. Dixit S, Purshottam S, Khanna S, Das M. Usage pattern of synthetic food colours in different states of India and exposure assessment through commodities preferentially consumed by children. Food Addit Contam Part A Chem Anal Control Expo Risk Assess. 2011;28(8):996-1005.

58. Tripathi M, Khanna SK, Das M. Surveillance on use of synthetic colours in eatables vis a vis Prevention of Food Adulteration Act of India. Food Control. 2007;18(3):211-9.

59. Stevens $\sqcup$, Burgess JR, Stochelski MA, Kuczek T. Amounts of artificial food colors in commonly consumed beverages and potential behavioral implications for consumption in children. Clin Pediatr. 2014;53(2):133-40.

60. Rao P, Bhat R, Sudershan R, Krishna T, Naidu N. Exposure assessment to synthetic food colours of a selected population in Hyderabad, India. Food Addit Contam. 2004;21(5):415-21.
61. Ashfaq N, Masud T. Surveillance on artifical colours in different ready to eat foods. Pakistan J Nutr. 2002;5:223-5.

62. Jonnalagadda PR, Rao P, Bhat RV, Nadamuni NA. Type, extent and use of colours in ready-to-eat (RTE) foods prepared in the non-industrial sector-a case study from Hyderabad, India. Int J Food Sci Technology. 2004;39(2):125-31.

63. Tsai C-F, Kuo C-H, Shih DY-C. Determination of 20 synthetic dyes in chili powders and syrup-preserved fruits by liquid chromatography/tandem mass spectrometry. J Food Drug Anal. 2015;23(3):453-62.

64. Moradi-Khatoonabadi Z, Amirpour M, AkbariAzam M. Synthetic food colours in saffron solutions, saffron rice and saffron chicken from restaurants in Tehran, Iran. Food Additives Contaminants: Part B. 2015;8(1):12-7.

65. Saleem N, Umar ZN. Survey on the use of synthetic food colors in food samples procured from different educational institutes of Karachi City. J Trop Life Sci. 2013;3(1):1-7.

66. Petigara Harp B, Miranda-Bermudez E, Barrows JN. Determination of seven certified color additives in food products using liquid chromatography. J Agricul Food Chem. 2013;61(15):3726-36.

67. Sood M. The supervision of government on implementation of import of processed food products in effort of legal protection for consumers. JL Pol'y \& Globalization. 2014;25:72.

68. Miller DD, Mariani S. Smoke, mirrors, and mislabeled cod: poor transparency in the European seafood industry. Front Ecol Environ. 2010;8(10):517-21.

69. Jacquet $J$, Pauly D. Trade secrets: renaming and mislabeling of seafood. Marine Policy. 2008;32(3):309-18.

70. Chin TC, Adibah A, Hariz ZD, Azizah MS. Detection of mislabelled seafood products in Malaysia by DNA barcoding: improving transparency in food market. Food Control. 2016;64:247-56.

71. Nagalakshmi K, Annam P-K, Venkateshwarlu G, Pathakota G-B, Lakra WS Mislabeling in Indian seafood: an investigation using DNA barcoding. Food Control. 2016:59:196-200.

72. Galal-Khallaf A, Ardura A, Mohammed-Geba K, Borrell YJ, Garcia-Vazquez E. DNA barcoding reveals a high level of mislabeling in Egyptian fish fillets. Food Control. 2014;46:441-5.

73. Cawthorn D-M, Steinman HA, Witthuhn RC. DNA barcoding reveals a high incidence of fish species misrepresentation and substitution on the South African market. Food Res Int. 2012;46(1):30-40.

74. Di Pinto A, Bottaro M, Bonerba E, Bozzo G, Ceci E, Marchetti P, et al. Occurrence of mislabeling in meat products using DNA-based assay. J Food Sci Technol. 2015;52(4):2479-84.

75. Carvalho DC, Palhares RM, Drummond MG, Gadanho M. Food metagenomics: next generation sequencing identifies species mixtures and mislabeling within highly processed cod products. Food Control. 2017;80:183-6.

76. Garcia-Vazquez E, Perez J, Martinez JL, Pardinas AF, Lopez B, Karaiskou N, et al. High level of mislabeling in Spanish and Greek hake markets suggests the fraudulent introduction of African species. J Agric Food Chemistry. 2010; 59(2):475-80.

77. Staffen CF, Staffen MD, Becker ML, Löfgren SE, Muniz YCN, de Freitas RHA et al. DNA barcoding reveals the mislabeling of fish in a popular tourist destination in Brazil. PeerJ. 2017:5:e4006.

78. Muñoz-Colmenero M, Juanes F, Dopico E, Martinez JL, Garcia-Vazquez E. Economy matters: a study of mislabeling in salmon products from two regions, Alaska and Canada (Northwest of America) and Asturias (Northwest of Spain). Fisheries Res. 2017;195:180-5.

79. Muñoz-Colmenero M, Blanco O, Arias V, Martinez JL, Garcia-Vazquez E. DNA authentication of fish products reveals mislabeling associated with seafood processing. Fisheries. 2016;41(3):128-38.

80. Bosko SA, Foley DM, Hellberg RS. Species substitution and country of origin mislabeling of catfish products on the US commercial market. Aquaculture. 2018:495:715-20.

81. Christiansen H, Fournier N, Hellemans B, Volckaert FA. Seafood substitution and mislabeling in Brussels' restaurants and canteens. Food Control. 2018; 85:66-75.

82. Galal-Khallaf A, Ardura A, Borrell YJ, Garcia-Vazquez E. PCR-based assessment of shellfish traceability and sustainability in international Mediterranean seafood markets. Food Chemistry. 2016;202:302-8.

83. Swanson NL, Leu A, Abrahamson J, Wallet B. Genetically engineered crops, glyphosate and the deterioration of health in the United States of America. J Organ Syst. 2014;9(2):6-37.

84. Pattron DD. A survey of genetically modified foods consumed, health implications and recommendations for public health food safety in Trinidad. Internet J Food Safety. 2005;7:4-14. 
85. Bakshi A. Potential adverse health effects of genetically modified crops. Toxicol Environ Health Part B. 2003;6(3):211-25.

86. Aris A, Leblanc S. Maternal and fetal exposure to pesticides associated to genetically modified foods in Eastern Townships of Quebec, Canada. Reprod Toxicol. 2011;31(4):528-33.

87. Anyanwu RC, Jukes DJ. Food systems and food control in Nigeria. Food Policy. 1991;16(2):112-26.

88. Burnett K, Skinner K, LeBlanc J. From Food Mail to Nutrition North Canada: reconsidering federal food subsidy programs for northern Ontario. Canadian Food Studies/La Revue canadienne des études sur l'alimentation. 2015;2(1): 141-56.

89. Freedman DA, Bell BA. Access to healthful foods among an urban food insecure population: perceptions versus reality. J Urban Health. 2009;86(6): 825-38.

90. Kunyanga C, Imungi JK, Okoth MW. Diversity and characteristics of supplementary foods sold and consumed by vulnerable groups in Kenya. J Applied Biosci. 2011;45:3019-31.

91. Rhodehamel E.J. Overview of biological, chemical, and physical hazards. In: Pierson M.D., Corlett D.A. (eds) HACCP. Springer, Boston, MA, 1992. DOI https://doi.org/10.1007/978-1-4684-8818-0_3

92. Aruoma Ol. The impact of food regulation on the food supply chain. Toxicology. 2006;221(1):119-27.

93. Horchner PM, Brett D, Gormley B, Jenson I, Pointon AM. HACCP-based approach to the derivation of an on-farm food safety program for the Australian red meat industry. Food Control. 2006;17(7):497-510.

94. Sun Y-M, Ockerman $H$. A review of the needs and current applications of hazard analysis and critical control point (HACCP) system in foodservice areas. Food Control. 2005;16(4):325-32.

95. Kleter G, Prandini A, Filippi L, Marvin H. Identification of potentially emerging food safety issues by analysis of reports published by the European Community's Rapid Alert System for Food and Feed (RASFF) during a four-year period. Food Chem Toxicol. 2009:47(5):932-50.

96. Ahl A, Buntain B. Risk and the food safety chain: animal health, public health and the environment. Revue Scientifique et Technique-Office International des Epizooties. 1997;16(2):322-30.

97. Scheule B, Sneed J. From farm to fork: critical control points for food safety. J Nutr Recipe Menu Dev. 2001;3(2):3-23.

98. Bagumire A, Todd EC, Nasinyama GW, Muyanja C, Rumbeiha WK, Harris C, et al. Potential sources of food hazards in emerging commercial aquaculture industry in sub-Saharan Africa: a case study for Uganda. Int J Food Sci Technol. 2009;44(9):1677-87.

99. Frewer $L$, Scholderer J, Bredahl L. Communicating about the risks and benefits of genetically modified foods: the mediating role of trust. Risk Anal. 2003;23(6):1117-33.

100. Albert I, Grenier E, Denis JB, Rousseau J. Quantitative risk assessment from farm to fork and beyond: a global Bayesian approach concerning foodborne diseases. Risk Anal. 2008;28(2):557-71.

101. Khairuzzaman M, Chowdhury FM, Zaman S, Al Mamun A, Bari M. Food safety challenges towards safe, healthy, and nutritious street foods in Bangladesh. Int J Food Sci. 2014;2014.

102. BALUKA SA, MILLER R, KANEENE JB. Hygiene practices and food contamination in managed food service facilities in Uganda. African J Food Sci. 2015;9(1):31-42.

103. Dharod JM, Paciello S, Bermúdez-Millán A, Venkitanarayanan K, Damio G, Pérez-Escamilla R. Bacterial contamination of hands increases risk of crosscontamination among low-income Puerto Rican meal preparers. J Nutr Educ Behav. 2009;41(6):389-97.

104. Paudyal N, Anihouvi V, Hounhouigan J, Matsheka Ml, Sekwati-Monang B, AmoaAwua W, et al. Prevalence of foodborne pathogens in food from selected African countries-a meta-analysis. Int Food Microbiol. 2017;249:35-43.

105. Henson S, Jaffee S. Food safety standards and trade: enhancing competitiveness and avoiding exclusion of developing countries. Eur J Dev Res. 2006;18(4):593-621.

106. Henson S, Jaffee S. Understanding developing country strategic responses to the enhancement of food safety standards. World Econ. 2008;31(4):548-68.

107. Grace D. Food safety in low and middle income countries. Int J Environ Res Public Health. 2015;12(9):10490-507.

108. Villanueva CM, Kogevinas M, Cordier S, Templeton MR, Vermeulen R, Nuckols JR, et al. Assessing exposure and health consequences of chemicals in drinking water: current state of knowledge and research needs. Environ Health Perspect. 2014;122(3):213-21.
109. Rather IA, Koh WY, Paek WK, Lim J. The sources of chemical contaminants in food and their health implications. Front Pharmacol. 2017;8:830.

110. Lawal B. Overview of the socioeconomic implications and management of product faking and adulteration. Greener J Bus Manag Stud. 2013;3(3):119-31.

111. Ayza A, Belete E. Food adulteration: its challenges and impacts. Food Sci Qual Manag. 2015;41:50-6.

112. Salih MAM, Yang S. Common milk adulteration in developing countries cases study in China and Sudan: a review. J Adv Dairy Res. 2017;5:192.

113. Nel S, Lues J, Buys E, Venter P. Bacterial populations associated with meat from the deboning room of a high throughput red meat abattoir. Meat science. 2004;66(3):667-74.

114. Podolak R, Enache E, Stone W, Black DG, Elliott PH. Sources and risk factors for contamination, survival, persistence, and heat resistance of Salmonella in low-moisture foods. J Food Protect. 2010;73(10):1919-36.

115. Nicolas B, Razack BA, Yollande I, Aly S, Tidiane OCA, Philippe NA, et al. Streetvended foods improvement: contamination mechanisms and application of food safety objective strategy: critical review. Pakistan J Nutri. 2007;6(1):1-10.

116. Legnani $P$, Leoni E, Berveglieri M, Mirolo G, Alvaro N. Hygienic control of mass catering establishments, microbiological monitoring of food and equipment. Food Control. 2004;15(3):205-11.

117. Sousa CPd. The impact of food manufacturing practices on food borne diseases. Brazilian Arch Biol Technology. 2008;51(4):615-623.

118. Carrasco E, Morales-Rueda A, García-Gimeno RM. Cross-contamination and recontamination by Salmonella in foods: a review. Food Res Int. 2012;45(2): 545-56.

119. Bansal S, Singh A, Mangal M, Mangal AK, Kumar S. Food adulteration: Sources, health risks, and detection methods. Crit Rev Food Sci Nutr. 2017. 57(6):1174-89.

120. Lyhs U, Korkeala H, Björkroth J. Identification of lactic acid bacteria from spoiled, vacuum-packaged 'gravad'rainbow trout using ribotyping. Int J Food Microbiol. 2002;72(1-2):147-53.

121. Rossi F, Gaio E, Torriani S. Staphylococcus aureus and Zygosaccharomyces bailii as primary microbial contaminants of a spoiled herbal food supplement and evaluation of their survival during shelf life. Food Microbiol. 2010;27(3):356-62.

122. Lyhs U, Björkroth JK. Lactobacillus sakei/curvatus is the prevailing lactic acid bacterium group in spoiled maatjes herring. Food Microbiol. 2008;25(3):529-33.

123. Hoffmann S, Scallan E. Epidemiology, cost, and risk analysis of foodborne disease. Foodborne Diseases, 3rd ediciton: Elsevier; 2017. p. 31-63. DOl: https://doi.org/10.1016/B978-0-12-385007-2.00002-4.

124. De Bon H, Parrot L, Moustier P. Sustainable urban agriculture in developing countries. A review. Agronomy Sustain Dev. 2010;30(1):21-32.

125. Abdulkadir A, Dossa L, Lompo D-P, Abdu N, Van Keulen H. Characterization of urban and peri-urban agroecosystems in three West African cities. Int J Agric Sustain. 2012;10(4):289-314.

126. Atidégla SC, Huat J, Agbossou EK, Saint-Macary H, Glèlè KR. Vegetable contamination by the fecal bacteria of poultry manure: case study of gardening sites in southern Benin. Int J Food Sci. 2016;2016.

127. Man SM. The clinical importance of emerging Campylobacter species. Nat Rev Gastroenterol Hepatol. 2011;8(12):669-85.

128. Li L, Mendis N, Trigui H, Oliver JD, Faucher SP. The importance of the viable but non-culturable state in human bacterial pathogens. Front Microbiol. 2014;5:258.

129. Fakruddin M, Mannan KS, Andrews S. Viable but nonculturable bacteria: food safety and public health perspective. ISRN Microbiol. 2013;2013:703813.

130. Ayrapetyan M, Oliver JD. The viable but non-culturable state and its relevance in food safety. Curr Opin Food Sci. 2016:8:127-33.

131. Onianwa P, Lawal J, Ogunkeye A, Orejimi B. Cadmium and nickel composition of Nigerian foods. J Food Comp Analys. 2000;13(6):961-9.

132. Vinci RM, Jacxsens L, Van Loco J, Matsiko E, Lachat C, de Schaetzen T, et al. Assessment of human exposure to benzene through foods from the Belgian market. Chemosphere. 2012;88(8):1001-7.

133. JY NIE, LX KUANG, ZX LI, WH XU, Cheng W, QS CHEN, et al. Assessing the concentration and potential health risk of heavy metals in China's main deciduous fruits. J Integr Agric. 2016;15(7):1645-55.

134. Schrenk D. Chemical food contaminants. Bundesgesundheitsblatt Gesundheitsforschung Gesundheitsschutz. 2004;47(9):841-7.

135. Thompson LA, Darwish WS. Environmental chemical contaminants in food: review of a global problem. J Toxicol. 2019;2019:2345283.

136. Palmer S, Bakshi KS. Chemical contaminants in food. Principles and practice of environmental medicine Chapter 3: Springer; 1992. p. 43-58. DOl: https:// doi.org/10.1007/978-1-4899-2447-6_3. 
137. Cao P, Yang D, Zhu J, Liu Z, Jiang D, Xu H. Estimated assessment of cumulative dietary exposure to organophosphorus residues from tea infusion in China. Environ Health Prev Med. 2018;23(1):7.

138. Minatoya M, Itoh S, Yamazaki K, Araki A, Miyashita C, Tamura N, et al. Prenatal exposure to bisphenol $A$ and phthalates and behavioral problems in children at preschool age: the Hokkaido Study on Environment and Children's Health. Environ Health Prev Med. 2018;23(1):43.

139. Mody RK, Griffin PM. Foodborne disease. Mandell, Douglas, and Bennett's principles and practice of infectious diseases 9th edition, 2 volume set: Elsevier; 2015. p. 1283-96. e3. eBook ISBN: 9780323550277

140. Rajakumar G, Manimegalai D. FPGA implementation of dip based adulteration identification in food samples. Int J Comput Appl. 2011:0975-8887.

141. Zhang W, Xue J. Economically motivated food fraud and adulteration in China: an analysis based on 1553 media reports. Food control. 2016;67:192-8.

142. Ravichandran S. Food adulteration has taken away the joy of life. Int J MediPharm Res. 2015;1(3):150-4.

143. Everstine K, Spink J, Kennedy S. Economically motivated adulteration (EMA) of food: common characteristics of EMA incidents. J Food Protect. 2013; 76(4):723-35.

144. Afzal A, Mahmood M, Hussain I, Akhtar M. Adulteration and microbiological quality of milk (a review). Pakistan J Nutr. 2011;10(12):1195-202.

145. McGwin G Jr, Lienert J, Kennedy J Jr. Formaldehyde exposure and asthma in children: a systematic review. Environ Health Perspect. 2009;118(3):313-7.

146. Baumgartner $M$, Flöck $M$, Winter $P$, et al. Evaluation of flow injection analysis for determination of urea in sheep's and cow's milk. Acta Veterinaria Hungarica. 2002;50(3):263-71.

147. See A, Abu BS, Fatimah AB, Nor AY, Ahmed SA, Heng L. Risk and health effect of boric acid. Am J Appl Sci. 2010;7(5):620-7.

148. Pressman P, Clemens R, Hayes W, Reddy C. Food additive safety: a review of toxicologic and regulatory issues. Toxicol Res Appl. 2017;1: 2397847317723572.

149. Codex general standard for the labelling of food additives when sold as such. CODEX STAN 107-198. Available at http://www.fao.org/3/y2770e/y2 770e03.htm. Accessed on 6 Aug 2019

150. Jay JM, Loessner MJ, Golden DA. Modern food microbiology: Springer Science \& Business Media; 2008. Available at https://www.springer.com/gp/ book/9780387231808. Accessed on 10 August 2019.

151. Neltner TG, Kulkarni NR, Alger HM, Maffini MV, Bongard ED, Fortin ND, et al. Navigating the US food additive regulatory program. Compr Rev Food Sci Food Saf. 2011;10(6):342-68.

152. Johnson PE. Health aspects of food additives. Am J Public Health Nations Health. 1966;56(6):948-51.

153. Jain A, Mathur P. Evaluating hazards posed by additives in food-a review of studies adopting a risk assessment approach. Curr Res Nutr Food Sci J. 2015: 3(3):243-55.

154. Armani A, Guardone L, La Castellana R, Gianfaldoni D, Guidi A, Castigliego L. DNA barcoding reveals commercial and health issues in ethnic seafood sold on the Italian market. Food Control. 2015;55:206-14.

155. Markoff $P$ and Leinberger K. Food mislabeling is more common than you think. Available at https://www.consumerlawchicago.com/blog/foodmislabeling-is-more-common-than-you-think.html. Accessed on 08 Aug 2019

156. Dona A, Arvanitoyannis IS. Health risks of genetically modified foods. Crit Rev Food Sci Nutr. 2009:49(2):164-75.

157. Conner AJ, Jacobs JM. Genetic engineering of crops as potential source of genetic hazard in the human diet. Mutation Research/Genetic Toxicology and Environmental Mutagenesis. 1999;443(1-2):223-34.

158. Bakke-McKellep A, Koppang E, Gunnes G, Sanden M, Hemre Gl, Landsverk T, et al. Histological, digestive, metabolic, hormonal and some immune factor responses in Atlantic salmon, Salmo salar L., fed genetically modified soybeans. Journal of Fish Diseases. 2007;30(2):65-79.

159. Paparini A, Romano-Spica V. Public health issues related with the consumption of food obtained from genetically modified organisms. Biotechnology annual review. 2004;10:85-122.

160. Halford NG, Shewry PR. Genetically modified crops: methodology, benefits, regulation and public concerns. Br Med Bull. 2000;56(1):62-73.

161. Conner AJ, Glare TR, Nap JP. The release of genetically modified crops into the environment: Part II. Overview of ecological risk assessment. Plant J. 2003:33(1):19-46.

162. Hashimoto W, Momma K, Yoon H-J, Ozawa S, Ohkawa Y, Ishige T, et al. Safety assessment of transgenic potatoes with soybean glycinin by feeding studies in rats. Bioscience Biotechnology biochemistry. 1999;63(11):1942-6.
163. Bernstein JA, Bernstein IL, Bucchini L, Goldman LR, Hamilton RG, Lehrer S, et al. Clinical and laboratory investigation of allergy to genetically modified foods. Environ Health Perspect. 2003;111(8):1114-21.

164. Acosta O, Chaparro A. Genetically modified food crops and public health. Acta Biologica Colombiana. 2008;13(3):3-26.

165. Pryme IF, Lembcke R. In vivo studies on possible health consequences of genetically modified food and feed-with particular regard to ingredients consisting of genetically modified plant materials. Nutrition Health. 2003; 17(1):1-8.

166. Omura $Y$, Price $R$, Olcott $H$. Histamine_forming bacteria isolated from spoiled skipjack tuna and jack mackerel. J Food Sci. 1978;43(6):1779-81.

167. Gram L, Ravn L, Rasch M, Bruhn JB, Christensen AB, Givskov M. Food spoilage - interactions between food spoilage bacteria. Int J Food Microbiol. 2002;78(1-2):79-97.

168. André S, Zuber F, Remize F. Thermophilic spore-forming bacteria isolated from spoiled canned food and their heat resistance. Results of a French tenyear survey. Int J Food Microbiol. 2013;165(2):134-43.

169. De Carvalho A, Costa E, Mantovani H, Vanetti M. Effect of bovicin HC5 on growth and spore germination of Bacillus cereus and Bacillus thuringiensis isolated from spoiled mango pulp. Journal of applied microbiology. 2007; 102(4):1000-9.

\section{Publisher's Note}

Springer Nature remains neutral with regard to jurisdictional claims in published maps and institutional affiliations.
Ready to submit your research? Choose BMC and benefit from:

- fast, convenient online submission

- thorough peer review by experienced researchers in your field

- rapid publication on acceptance

- support for research data, including large and complex data types

- gold Open Access which fosters wider collaboration and increased citations

- maximum visibility for your research: over $100 \mathrm{M}$ website views per year

At $\mathrm{BMC}$, research is always in progress.

Learn more biomedcentral.com/submissions 